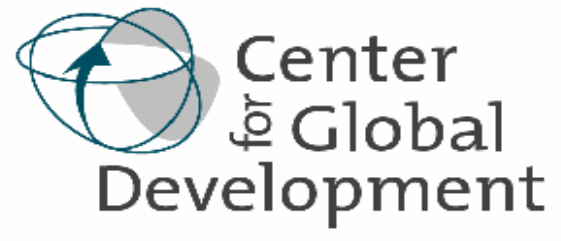

Working Paper Number 66

August 2005

Production-weighted Estimates of Aggregate Protection in Rich Countries toward Developing Countries

By David Roodman

Abstract
A challenge in the development of aggregate indexes of trade protection is finding
weights to put on various tariffs that a) reflect their importance to exporters and b) are not
endogenous to the protection being measured. One common basis for weights is actual
imports; but these, as is well-known, are endogenous. Various authors have worked to
correct this endogeneity, but doing so is difficult in product areas where protection is
both high and widespread. For this reason, I develop a new set of estimates of overall
protection in rich countries with respect to developing ones that eschews import weights
as much as possible in favor of weights based on the value of exporter's total production
in each product area. The results are generally much higher than those from the Bouët et
al. (2004) "MAcMap” data set; there, weights are based on imports of large reference
groups of countries. I conclude that product areas in which protection is high and wide-
spread are systematically de-emphasized when using pure MAcMap weights to aggregate
across major product groups. In particular, when gauging rich-country protection with
respect to developing countries, agriculture is de-emphasized. I also develop estimates of
trade-distorting subsidies by country and commodity and translate these into tariff-
equivalents with the methodology of Cline (2004) in order to estimate overall protection
levels. Agricultural tariffs dominate subsidies in trade-distorting effect, and agricultural
protection in turn dominates goods protection generally. Japan is most protective, largely
because of rice tariffs near 900\%, followed by Norway and Switzerland. Because of their
greater reliance on agriculture, the poorest countries face higher trade barriers than
wealthier developing countries, despite tariff preferences.




\title{
Production-weighted Estimates of Aggregate Protection in Rich Countries toward Developing Countries
}

\author{
David Roodman ${ }^{1}$ \\ Center for Global Development
}

August 2005

\begin{abstract}
A challenge in the development of aggregate indexes of trade protection is weighting individual tariffs in ways that a) reflect their importance and b) are not endogenous to the protection being measured. The most obvious basis for weights is actual imports; but these may be highly endogenous. Various authors have worked to correct this endogeneity. For example, in the Bouët et al. (2004) "MAcMap" data set, weights are based on imports of reference groups of countries. But eliminating the endogeneity is difficult in product areas where protection is high and widespread. I develop a new set of estimates of overall protection in rich countries with respect to developing ones that eschews import weights as much as possible in favor of weights based on the value of exporter's total production. The results are generally higher than those of Bouët et al. Product areas in which protection is high and widespread seem systematically de-emphasized when using MAcMap weights, especially in agriculture. I also estimate tariff equivalents of trade-distorting subsidies by country and commodity. Agricultural tariffs dominate subsidies in trade-distorting effect, and agricultural protection in turn dominates goods protection generally. Japan is most protective, largely because of rice tariffs near $900 \%$, followed by Norway and Switzerland. Because of their greater reliance on agriculture, the poorest countries face the highest barriers, despite tariff preferences.
\end{abstract}

Keywords: Agricultural subsidies, tariffs, aggregate protection, Doha Round

\footnotetext{
${ }^{1}$ William Cline guided this work. I thank Betina Dimaranan of the Global Trade Analysis Project and David Laborde of the Centre d'Etudes Prospectives et d'Informations Internationales for assistance with data; Tom Hertel, Dominique van der Mensbrugghe, Peter Timmer, Kim Elliott, Agapi Somwaru, and John Wainio for their contributions to the November 2004 meeting that gave impetus to this work; and two anonymous reviewers for valuable comments.
}

The final version of this paper is published in World Economy 30(6), pp. 999-1028 (June 2007). 
Rich-country trade barriers to the exports of poor countries have been a high-profile issue in the current, struggling negotiations to revise the General Agreement on Tariffs and Trade. The substrates upon which trade negotiators work are the thousand-line tariff schedules maintained by their customs authorities, along with complicated non-tariff barriers including quotas and subsidies. But among both negotiators and interested observers, there has long been an interest in aggregate measures of protection. Which product groups have the highest barriers? Which countries face the highest protection and which impose it? Those who observe and influence the negotiations, including politicians, non-governmental groups, and journalists, seek the big picture. For negotiators, the interest arises in part out of the search for reciprocating cross-sector deals, which create a need to compare, say, France's agricultural protection with Brazil’s steel protection (Cooper 1966).

The need for the big picture has long led economists to developed aggregate indexes of protection, usually expressed in ad valorem tariff-equivalent terms (Corden 1966; Cooper 1966; Basevi 1971; Anderson and Neary 1994, 1996, 2003; OECD 1997; Bouët et al. 2004; Cline 2002, 2004; IMF 2005; Kee, Nicita, and Olarreaga 2004, 2006). The approaches can be classified in various ways. Some are expedient, others more theoretically sound. Some are partial equilibrium, some general. Different indexes also mean different things and answer different questions. For example, the interest in the domestic implications of a country's own trade policies has often led to weighting of border measures by the value of domestic production in each sector (Basevi 1971).

Here, however, motivated by the recent controversy, we are interested in how a country's barriers affect other countries, in particular, how each rich country's barriers affect poor ones as a group. ${ }^{2}$ The ap-

\footnotetext{
${ }^{2}$ This work is part of the Commitment to Development Index (Roodman 2006a), which rates the "development friendliness" of rich countries in trade and other policy areas.
} 
proach we take is simpler than that of Kee, Nicita, and Olarreaga, who run thousands of regressions in order to estimate 315,451 distinct import elasticities in various countries (as one step in their calculation). Taking a weighted average of individual barriers, the approach is akin to that of Bouët et al. (2004). But it incorporates agricultural subsidies, and avoids what appears to be a problem of endogeneity in their weights.

The challenges in developing aggregate measures of trade policy are well known. The raw data on tariffs and other barriers are complex and often incomplete. Tariff line divisions below the 6-digit level vary by country. It is hard to estimate key parameters, such as supply and demand elasticities, that determine welfare cost of various barriers. But without an understanding of the costs, it is hard to know, for example, whether a tariff twice as high is twice as bad. There are theoretical challenges in comparing barriers, such as tariffs and quotas, that are fundamentally different.

In addition, there is the challenge of weighting. Tariffs against major goods obviously matter more than those against obscure ones, and so ought to be given more weight. But what should be the basis for weights? One natural choice is the value of imports of the good in question, especially tempting since imports data are often available at the same resolution as tariff data. But this leads to an old endogeneity problem: categories with the most protection can get the least weight. ${ }^{3}$ Attempts have been made to estimate counterfactual import levels in the absence of protection. Cline, for example, computes “adjusted import weights” for broad sectors such as agriculture based on certain assumptions about the elasticity of demand and supply for imports. Bouët et al. use observed import levels of large reference groups of countries, which are less endogenous to protection in any one country. But neither approach is reliable in

\footnotetext{
${ }^{3}$ This is not automatically so. To the extent that the political economy of protection causes barriers to be higher for goods with high imports, observed imports and protection will be positively correlated (Corden 1996; Cline 2002). But if this effect dominates, import weighting is still be biased, just in the opposite way.
} 
product areas where protection is both high and widespread, as it is in agriculture, textiles, and apparel, the areas of most concern to developing countries. When protection is very high, extrapolated estimates of imports in the absence of protection become too heroic; when it is widespread, reference groups do not work.

This paper eschews import weights as much as possible in favor of weights based on exporter's production—a choice that reflects our interest in the impact of protection on exporters. The value of Vietnam's rice output, for example, is taken as the best available indicator of its propensity to export rice to Japan—better than its actual exports to Japan, however adjusted, and better than its exports to other countries, where it also faces barriers. This system is similar to that of the OECD (1997), with the crucial difference that it substitutes exporter's for importer's production. The underlying protection data come from Bouët et al.'s detailed MAcMap data set, while the data for production weights come from the Global Trade Analysis Project version 6 database. Section 1 details the methodology and uses it to measure protection in individual rich countries with respect to developing countries as a group, by which I mean essentially all countries that are not members of the Development Assistance Committee (DAC). Section 2 integrates estimates of the tariff equivalent of agricultural subsidies, derived with the methodology of Cline (2002, 2004), in order to calculate overall levels of protection in rich countries from the developing country point of view, in agriculture specifically and goods generally. Section 3 briefly concludes.

\section{Aggregate tariff barriers}

Antoine Bouët, Lionel Fontagné, and colleagues at the Centre d'Etudes Prospectives et d'Informations Internationales (CEPII) and the International Trade Centre make a formidable attack on the protection- 
measurement problem at the tariff line level in their Market Access Map (MAcMap) data set. One sign of the value of their work is that the Global Trade Analysis Project (GTAP) switched to MAcMap data in version 6 of the GTAP modeling product. MAcMap provides ad valorem tariff equivalents of tariffs by importer, exporter, and 6-digit line in the Harmonized System of product classification (HS 6). The data set has some 35 million rows in all. The MAcMap data also factor in preferences for least developed countries. And they embody considerable effort on methodologies for converting tariff-rate quotas (TRQs) and specific-unit tariffs into ad valorem-equivalent simple tariffs. TRQs, which rich countries apply primarily in agriculture, are pairs of tariffs: a low one applies to imports within some quota, and a high one applies beyond. They originated in Uruguay Round commitments to "tarify" what were once quotas. Specific-unit tariffs, including those in TRQs, are ones expressed in physical terms such as per ton or head of cattle. Finally, the MAcMap data contain a fresh approach to reducing the endogeneity of import weights, which involves clustering importers into reference groups. The weight for a given barrier is based on imports not just of the country imposing the barrier but of all countries in its group. The weights, like the tariff estimates, are provided for each combination of importer, exporter, and HS 6 line.

However, some aggregate results from MAcMap differ surprisingly from previous results. In particular, trade barriers in rich countries with respect to poorer countries appear quite low. (See Table 1.) Seemingly, despite all the Doha Round controversy, rich-country tariffs are a minor problem for developing countries. And to the extent they are a problem, Australia appears to be the greatest offender, rather than Japan, Norway, or Switzerland, the rich countries usually seen as most protective. These results differ substantially from those in Cline (2004) and Kee, Nicita, and Olarreaga (2006). 
Table 1. Ad valorem equivalent of trade barriers with respect to middle-income and least-developed country exporters, $2001(\%)$

\begin{tabular}{lcc} 
Importer & $\begin{array}{c}\text { Middle-income } \\
\text { exporters }\end{array}$ & LDC exporters \\
\hline Australia & 5.6 & 8.4 \\
Canada & 3.1 & 6.3 \\
EU-15 & 2.7 & 0.8 \\
Japan & 4.1 & 2.0 \\
New Zealand & 2.8 & 4.0 \\
Switzerland & 3.5 & 0.6 \\
United States & 2.6 & 5.9 \\
\hline
\end{tabular}

Source: Bouët et al. (2004).

Motivated by the need to update and refine the trade component of the Commitment to Development Index for 2005 (Roodman 2006a), I obtained the MAcMap data set and explored alternative aggregation approaches. The goal was to take advantage of the MAcMap authors' careful work at the sub-HS 6 level while investigating and correcting potential endogeneity problems that would explain results like those in Table 1. The main concern is that MAcMap’s use of reference groups still produces import weights that are substantially endogenous. In particular, agricultural protection, which turns out to drive overall results, is high in most rich countries.

To reduce the endogeneity, I experiment with what can be thought of as four distinct changes to the MAcMap aggregation. The thrust throughout is to base weights on the value of exporter's production rather than exports. But production figures are not available at the high resolution of HS 6. The best available data appear to be from the GTAP 6.0 database; there one can find the value of world production of goods and services broken down by 87 country/regions and 57 product groups. ${ }^{4}$ Taking advantage of this data for weighting therefore requires that the MAcMap data be aggregated in two steps: first

\footnotetext{
${ }^{4}$ The 57 include services, which are not relevant here because MAcMap, like all such databases, lacks information on protection in services.
} 
to the GTAP level, then to the universal level. This must be done along each of two dimensions: product groups and exporters. Thus there are four aggregation steps, and in each step I experiment with one change:

1) To aggregate across HS 6 lines within GTAP product categories, I use MAcMap weights or simple averaging — whichever gives the higher number. This increases the sensitivity to the phenomenon of high barriers across an entire reference group of importers for a given product.

2) To aggregate across countries within a GTAP region, I weight by exchange-rate GDP rather than MAcMap weights. This is relevant only for GTAP regions that in fact consist of more than one country, such as "Rest of Sub-Saharan Africa." GDP is a coarse indicator of propensity to export, but has the advantage of not being very endogenous to protection faced, and does distinguish appropriately between large and small countries.

3) To aggregate across GTAP regions, to the full universe of non-DAC countries, I weight by the value of exporter's production in the product category.

4) To aggregate across GTAP product groups to the full universe of traded goods, I weight in the same manner.

These steps reduce but do not eliminate endogeneity. Production too is endogenous to protection faced; even GDP is to some extent. Moreover, the partial reliance on MAcMap weighting within GTAP product categories (change 1) also means that imports still enter.

To investigate the relative significance of these changes, I perform six variants of the original MAcMap aggregation —-the aggregation, that is, that relies purely on MAcMap's distinctive reference group import weights. Variant 1 makes changes 1 and 2-and performs the modified steps in that order—but uses 
MAcMap weights thereafter, in order to determine the importance of changing how data are aggregated up to the GTAP level. Variant 2 makes changes 1-3 while Variant 3 makes only change 4 because, it will emerge, change 4 is the one of central importance. Variant 4 makes all the changes. Variant 5 makes all changes too, but swaps the first two steps. If all the steps simply took weighted averages, this swap would have no effect. But because change 1 involves the maximum operator, order matters.

Finally, Variant 6 drops change 1 but implements the other changes, and is my preferred variant; the maximum operator in change 1 is relatively atheoretical and turns out to have a small effect on the absolute results and almost no effect on the relative results. Thus Variant 6 is a true weighted average of MAcMap values. It still aggregates across HS 6 lines within GTAP product groups using MAcMap weights, but aggregates across exporters within GTAP country/regions by exporter's GDP and across GTAP product groups and country/regions by the value of exporter's production. Table 2 has the results.

Table 2. Protection with respect to non-DAC countries, 2001, various aggregation systems (ad valorem equivalent, \%)

\begin{tabular}{|c|c|c|c|c|c|c|c|c|}
\hline \multirow[b]{2}{*}{ Country } & \multirow{2}{*}{$\begin{array}{c}\text { With } \\
\text { MAcMap } \\
\text { weighting }\end{array}$} & \multicolumn{6}{|c|}{ Variant } & \multirow{2}{*}{$\begin{array}{c}\text { Variant } 6+\text { export } \\
\text { tax equivalents of } \\
\text { textile \& apparel } \\
\text { quotas }\end{array}$} \\
\hline & & 1 & 2 & 3 & 4 & 5 & 6 & \\
\hline Australia & 5.44 & 5.71 & 5.62 & 4.36 & 4.73 & 4.49 & 4.36 & 4.36 \\
\hline Canada & 3.04 & 3.33 & 3.21 & 4.23 & 4.51 & 4.39 & 3.93 & 4.77 \\
\hline EU-15 & 2.66 & 3.06 & 2.96 & 8.19 & 8.42 & 8.86 & 7.46 & 9.13 \\
\hline Japan & 3.48 & 4.25 & 4.21 & 25.76 & 29.48 & 28.32 & 26.90 & 26.90 \\
\hline New Zealand & 2.64 & 2.99 & 2.97 & 2.31 & 3.03 & 2.77 & 2.55 & 2.55 \\
\hline Norway & 3.45 & 4.67 & 4.76 & 16.77 & 19.99 & 19.50 & 16.83 & 16.83 \\
\hline Switzerland & 4.11 & 5.30 & 4.80 & 11.25 & 13.27 & 12.97 & 11.00 & 11.00 \\
\hline United States & 2.35 & 2.68 & 2.81 & 2.61 & 3.24 & 2.96 & 2.83 & 4.08 \\
\hline
\end{tabular}

It is apparent that change 4—weighting across GTAP product groups by exporter's production rather than MAcMap import weights—makes the biggest difference. To see this, note that the variants break into two groups going by results. Variants 1 and 2 do not make change 4 and yield results similar to the 
MAcMap original. Variants 3-5 include change 4 (indeed, it is the only change they all share) and produce similar and generally higher values. This suggests that product areas in which protection is high and widespread in rich countries are systematically de-emphasized when using pure MAcMap weights. It also goes a long way to explaining the difference between the MAcMap aggregates in Table 1 and those in, for example, Cline (2002, 2004).

The detailed appendix Table A-1 further illuminates the key difference. It has one row for each richcountry importer and GTAP product group. The "tariffs" column shows the estimated tariff level by importer and product group, as used in the preferred Variant 6 - tariff levels derived, that is, by aggregating across HS 6 lines to GTAP product categories by MAcMap weight, and across countries to GTAP regions by GDP. The next column shows the MAcMap weights for each importer-product group combination. The one after shows weights based on exporters' production. Both weight sets are adjusted to sum to $100 \%$ for each importer. (The next section explains the final two columns.) In agricultural categories, most exporter’s production weights are much higher than MAcMap weights. For example, the EU's estimated $90 \%$ tariff on sugar from non-DAC countries gets only $0.15 \%$ weight in the MAcMap system but $0.76 \%$ going by exporter’s production, a 5-fold difference. By the same token, MAcMap gives more weight to manufactures, where rich-country protection is generally low—but where Australian protection is relatively high. This explains the poor relative result for Australia in the pure MAcMap approach.

Given the high protection levels throughout the group of rich countries in certain categories, especially agriculture, it seems likely that the MAcMap reference-group system, when used for aggregation across major product categories, leads to substantial underestimates of protection. A similar endogeneity bias 
may also operate within product groups, but the similarity of results between Variants 5 and 6 (which differ only in whether they use the simple average as a floor for the MacMAp-weighted average) offers reassurance that the bias is not too large. It might be argued that exporter's production weights are also misleading, that Thailand and Vietnam have much less propensity to export rice than produce it. But then why do rich countries maintain such high barriers against them?

These estimates are for the data year of 2001, at which time Canada, the European Union, and the United States maintained textile and apparel import quotas. Francois and Spinanger estimate the export tax equivalents of these quotas. I use the version of their estimates that are free of some constraints imposed for consistency with GTAP 6.0. The final column of Table 2 shows what happens when these export tax equivalents are chained with tariffs in the GTAP “textiles” and "wearing apparel” categories. Since the quotas ended on January 1, 2005, they are left out of all results reported hereafter.

Table 3 and Table 4 decompose the results for the preferred Variant 6 by exporter's region and income group, using World Bank definitions of these categories. There is some evidence that rich countries erect the highest barriers against those regions with which they have the most propensity to trade. Japan's protection is highest against its neighbors in Asia while the Swiss and Norwegians put the highest tariffs on goods from the Americas, with Eastern Europe a close second. More importantly, in the stratification by income group, there is little sign that preferences for the poorest countries are a major factor. ("Upper income” here refers to non-DAC exporters such as Hong Kong and Slovenia.) EU tariffs against lowincome countries average $6.54 \%$, only slightly below the $7.84 \%$ for lower-middle income countries, and well above the $3.85 \%$ for high-income countries. Norwegian and Swiss tariffs are actually measured as higher for low-income countries that lower-middle income ones. And the highest number in the table is 
for Japan’s protection with respect to low-income countries, a striking $40.12 \%$.

Table 3. Protection with respect to non-DAC countries, 2001, by region, Variant 6 (ad valorem equivalent, \%)

\begin{tabular}{|c|c|c|c|c|c|}
\hline Country & Americas & $\begin{array}{l}\text { East and } \\
\text { South Asia }\end{array}$ & $\begin{array}{l}\text { Middle East } \\
\& \text { N. Africa }\end{array}$ & $\begin{array}{l}\text { Eastern } \\
\text { Europe }\end{array}$ & $\begin{array}{c}\text { Sub-Saharan } \\
\text { Africa }\end{array}$ \\
\hline Australia & 4.7 & 4.5 & 4.1 & 4.2 & 3.2 \\
\hline Canada & 4.1 & 3.8 & 3.7 & 4.3 & 2.2 \\
\hline EU-15 & 7.6 & 8.9 & 4.6 & 5.5 & 4.3 \\
\hline Japan & 15.8 & 36.0 & 19.4 & 18.3 & 21.7 \\
\hline New Zealand & 2.4 & 3.0 & 1.6 & 2.3 & 1.5 \\
\hline Norway & 21.2 & 13.7 & 15.2 & 20.6 & 16.5 \\
\hline Switzerland & 16.8 & 7.2 & 12.9 & 14.6 & 7.9 \\
\hline United States & 2.2 & 3.5 & 1.9 & 2.4 & 1.3 \\
\hline
\end{tabular}

Table 4. Protection with respect to non-DAC countries, 2001, by income group, Variant 6 (ad valorem equivalent, \%)

\begin{tabular}{lrrrrr} 
Country & Low income & $\begin{array}{c}\text { Lower middle } \\
\text { income }\end{array}$ & $\begin{array}{c}\text { Middle in- } \\
\text { come }\end{array}$ & $\begin{array}{c}\text { Upper middle } \\
\text { income }\end{array}$ & $\begin{array}{c}\text { Upper in- } \\
\text { come }\end{array}$ \\
\hline Australia & 3.96 & 4.22 & 4.35 & 5.06 & 3.84 \\
Canada & 3.06 & 3.88 & 4.22 & 3.86 & 3.38 \\
EU-15 & 6.54 & 7.84 & 5.95 & 7.13 & 3.85 \\
Japan & 40.12 & 25.02 & 13.85 & 25.47 & 14.79 \\
New Zealand & 4.95 & 2.45 & 2.18 & 2.85 & 1.89 \\
Norway & 18.81 & 16.39 & 18.80 & 5.64 & 8.62 \\
Switzerland & 11.89 & 9.88 & 13.74 & 6.43 & 9.38 \\
United States & 2.29 & 3.11 & 2.05 & 2.83 & 1.85 \\
\hline
\end{tabular}

\section{A closer look at agriculture}

Especially now that the old quotas on textiles and apparel have been abolished, domestic agricultural subsidies loom as the most important non-tariff trade impediment maintained by rich countries. It is often said that OECD governments spend \$300 billion a year subsidizing agricultural production. Although aid to rich-country farmers is copious, the $\$ 300$ billion figure is wrong, so phrased. Rather, OECD farmers and food buyers receive support by virtue of government policy that is equivalent to nearly \$300 billion in subsidies, as measured by the OECD’s (2004) Total Support Estimate (TSE). Much of this benefit is actually delivered in the form of tariffs, which the OECD converts to subsidy equivalents. Much of the rest includes "general services” such as agricultural education and R\&D, trans- 
fers to consumers rather than producers, and transfers to producers in ways that create little incentive for additional production, thus little trade distortion.

The purpose at hand is to measure government payments that distort trade, which calls for a narrower definition of subsidy. This section offers such a definition, and how the subsidy totals generated by it are converted to tariff equivalents in order to allow comparison with the previous section's results.

Table 5 lays out the subsidy definition with aggregates across all agricultural products covered in order to give a sense of the magnitudes involved. The OECD tracks three major kinds of support: support to producers, general services such as agricultural extension and inspection services, and support to consumers. The first major subcategory of producer support is Market Price Support (MPS, row B of the table), which is the additional income accruing to producers because their farmgate prices are higher than world prices. Governments maintain these price differentials with two kinds of border measures: barriers to imports and subsidies for exports. Import barriers account for the lion's share of MPS in OECD countries and, because they generate transfers from domestic consumers to domestic producers, also show up as negative entries under support to consumers (row T). Spending on export subsidies can be inferred by taking the algebraic sum of MPS and transfers from consumers to producers (see row X).

The other subcategories of producer support do represent government expenditure. And many of these are counted here as distorting production, including "Payments based on output, "Payments based on area planted/animal numbers," “Counter cyclical payments," "Payments based on input use," and "Payments based on input constraints." "Payments based on historical entitlements" are also counted, but at 50 cents on the dollar. In theory, these subsidies are decoupled from present production and shouldn't 
distort it, but they are often administered in ways that do. For example, the U.S. formally decoupled many support payments in 1996—but then disbursed an extra $\$ 8.6$ billion/year in “emergency assistance” during 1998-2001, and in 2002 allowed farmers to update the base figures for their "decoupled" subsidies. And some EU payments are decoupled only at the national or regional level. Allocation within regions is still based on actual production (de Gorter, Ingco, and Ignacio 2003).

To these are added export subsidies. Throughout, three-year averages are used because subsidy levels are sensitive to volatile world prices and the weather. For the countries of interest here, total tradedistorting subsidies are estimated at $\$ 77.5$ billion/year for 2001-03. Of this, only $\$ 2.7$ billion is export subsidies, the type often singled out by NGOs and politicians 
Table 5. Production-distorting agricultural payments and Total Support Estimate of OECD, 2001-03 averages

N. Zea- Switzer- United

Australia Canada EU-15 Japan land Norway land States Total (\$)

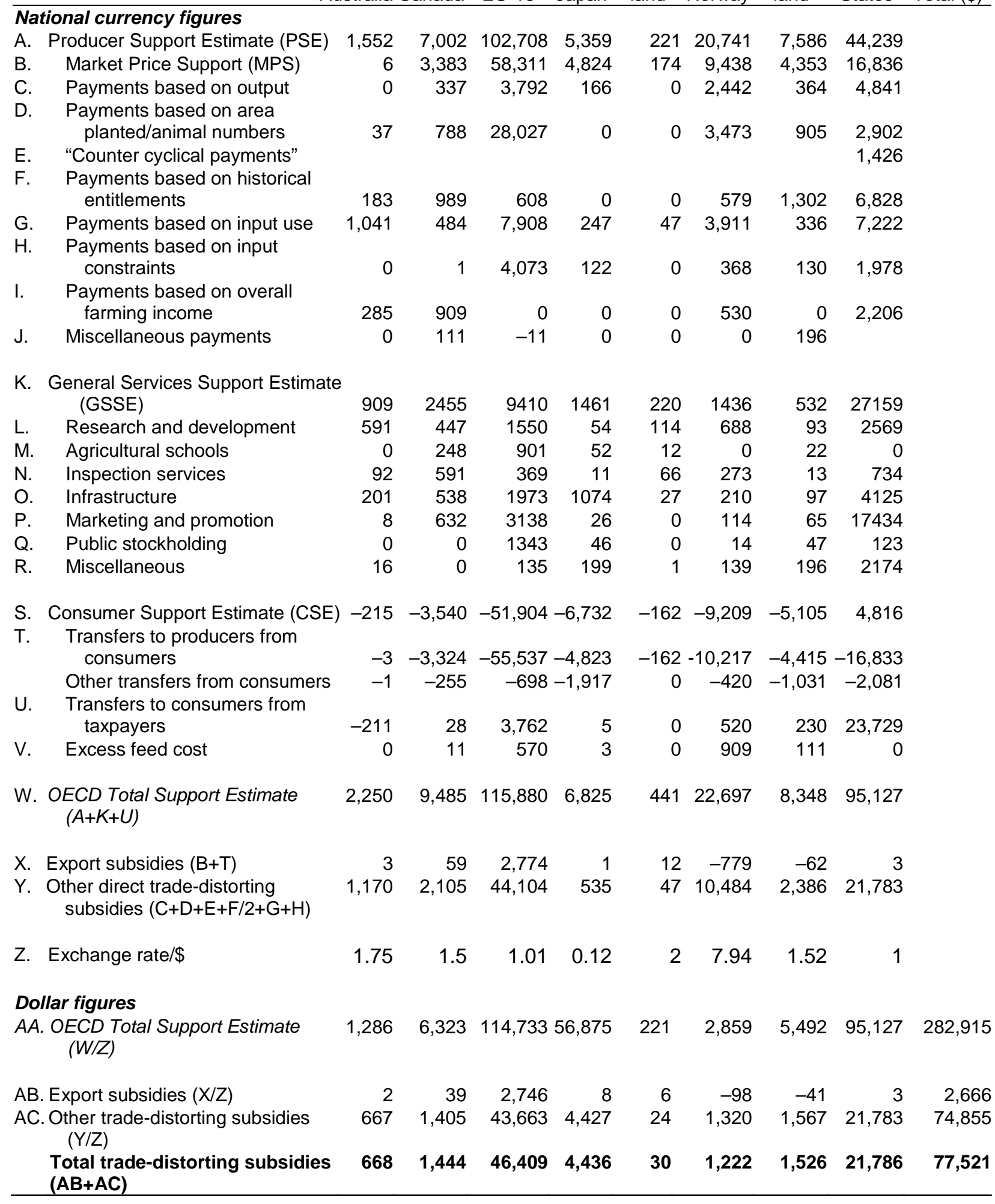


The aggregate data in Table 5 do not in fact enter the calculations described here. Rather, more detailed data from the OECD (2004) by commodity group (beef, oats, etc.) are used, in the same way. The OECD and GTAP databases categorize agricultural products differently; some GTAP categories are subdivided in the OECD subsidy database, and vice versa in the case of rice, which GTAP splits between paddy and processed rice. In order to integrate the two agricultural data sets, I aggregate both into 9 supercategories, 8 of which are strict GTAP categories and one of which is rice. Again, I aggregate the tariff estimates using production weights.

The formula for translating production subsidies into tariff equivalents is based on Cline (2004, ch. 3). It derives from a partial equilibrium analysis that asks what uniform ad valorem tariff level would depress imports as much as a given production subsidy. Inputs to the formula are subsidies, $s$, and imports, $\varphi_{M}$, both as shares of the farmgate value of production; the ad valorem tariff equivalent of border measures, $t$; and the absolute value of the price elasticity of demand for imports, $\beta$. $\beta$ is in turn estimated as $\sigma_{D}(1-$ $\phi_{M}$ ), where $\sigma_{D}$ is the elasticity of substitution in demand between domestic goods and imports, assumed to be 3.6, and $\phi_{M}$ is imports/consumption at world prices. Cline shows that, assuming that the elasticity of domestic supply is 1 , a production subsidy causes a proportionate reduction in imports equal to ${ }^{5}$

$$
1+\varphi_{M}(1+t)\left(1+\frac{1}{s}\right)
$$

Meanwhile, the proportionate reduction caused by an additional and hypothetical ad valorem tariff, $\tau$, in place of the subsidy would be

$$
(1+\tau)^{\beta}
$$

\footnotetext{
${ }^{5}$ This is algebraically equivalent to Equation A8 of Cline 2004, Appendix 3A-2.
} 
Equating the two expressions and solving yields the tariff-equivalent of the subsidy:

$$
\tau=\left(1+\frac{1}{1+\varphi_{M}(1+t)\left(1+\frac{1}{s}\right)}\right)^{1 / \beta}-1
$$

This is the formula for the final column of Table A-2, which exhibits the calculations for each importer and product group. ${ }^{6}$ Import and export data in the table are from the UNCTAD COMTRADE database, and are averages for 2002-03. ${ }^{7}$

The final two columns of appendix Table A-1 chain these subsidy tariff-equivalents with tariffs derived under Variant 6 in the previous section, in order to obtain estimates of overall protection in agriculture with respect to non-DAC countries. Table 6 summarizes the results for agriculture, by major commodity group. Table 7 performs the final aggregations, across all agriculture and across all goods.

Australia and New Zealand have extremely low agricultural tariffs against developing countries, at $0.83 \%$ and $0.37 \%$ in across-the-board ad valorem terms. New Zealand matches the low tariffs with

\footnotetext{
${ }^{6}$ This is nearly equivalent to equation A10 of Cline (2004, ch. 3, appendix 3A-2), differing only in that the elasticity $\beta$ enters as an exponent. Cline's formula is equivalent to

$$
\tau=\frac{1}{\beta} \frac{1}{1+\varphi_{M}(1+t)\left(1+\frac{1}{s}\right)},
$$

which is the first term in a Taylor expansion of the formula used here.

${ }^{7} 2001$ data are not available via the web interface for this database.
} 
minimal subsidies, equivalent to just 1.09\% in tariff terms; but subsidies in Australia are somewhat more substantial, equivalent to a $6.37 \%$ tariff. Along with the United States, the next-lowest on tariffs, these three countries impede agricultural imports from developing countries more through subsidies than tariffs. All, however, maintain relatively low barriers in aggregate. The other rich countries, especially Japan, Norway, and Switzerland, have higher barriers, which are imposed mainly through tariffs. This is perhaps not surprising since tariffs are cheaper for a government than subsidies. Moreover, production subsidies are not as efficient at impeding imports. Paying a farmer based on outputs, inputs, etc., does not as directly interfere with imports.

The correlations between the top and bottom halves of Table 7 suggest that agricultural protection is in turn the dominant source of variation in levels of overall protection in goods. An examination of the details in Table A-1 bears this out. Protection tends to be much lower in textiles, apparel, and other manufactures, for example. In sum, then, agricultural tariffs are the major source of difference among rich countries in protection with respect to poor ones. Switzerland, Norway, and Japan impose the highest agricultural tariffs, equivalent to uniform ad valorem tariffs of 50.86\%, 89.44\%, and $158.14 \%$ respectively, and are also highest in overall goods protection, in the same order.

The final column of Table 7 compares this paper's results with those of Cline (2004). The differences are remarkably small for the EU-15 and United States, despite Cline’s use of a different methodology and GTAP 5 data. The factor-two difference for Japan appears to be largely explained by different estimates for the tariff equivalent of rice TRQs. GTAP 5 used the simple average of the two tariffs in a TRQ. MAcMap uses the low rate when quotas are less than 90\% filled, the simple average for fill rates of $90-100 \%$, and the high rate for fill rates above 100\%.GTAP 5 puts Japanese paddy and process rice 
tariffs both at 409\% (Dimaranan and McDougall 2002, p. 4-6). The MAcMap-based figures reported here (Table A-1) are $844 \%$ and $919 \%$.

Table 6. Ad valorem tariffs with respect to non-DAC countries and tariff-equivalents of subsidies, agriculture, by importer and major product group (\%)

\begin{tabular}{|c|c|c|c|c|c|c|c|c|c|c|}
\hline Importer & Rice & Wheat & $\begin{array}{c}\text { Corn \& } \\
\text { other } \\
\text { grains }\end{array}$ & Sugar & $\begin{array}{c}\text { Vege- } \\
\text { tables, } \\
\text { fruit, } \\
\text { nuts }\end{array}$ & $\begin{array}{c}\text { Beef \& } \\
\text { sheep- } \\
\text { meat }\end{array}$ & $\begin{array}{l}\text { Pork, } \\
\text { poul- } \\
\text { try, } \\
\text { other } \\
\text { meat }\end{array}$ & $\begin{array}{l}\text { Dairy, } \\
\text { eggs }\end{array}$ & $\begin{array}{c}\text { Oil } \\
\text { seeds }\end{array}$ & Wool \\
\hline \multicolumn{11}{|l|}{ Tariffs, 2001} \\
\hline Australia & 0.0 & 0.0 & 0.0 & 10.0 & 0.8 & 0.0 & 0.7 & 0.9 & 0.8 & 0.2 \\
\hline Canada & 0.0 & 2.6 & 0.3 & 4.5 & 1.8 & 8.4 & 39.5 & 97.7 & 0.0 & 0.0 \\
\hline EU-15 & 110.8 & 0.7 & 17.2 & 90.4 & 19.1 & 75.8 & 15.2 & 38.0 & 0.0 & 0.0 \\
\hline Japan & 886.7 & 214.4 & 53.2 & 227.0 & 21.4 & 38.2 & 36.5 & 82.4 & 1.6 & 1.2 \\
\hline New Zealand & 0.0 & 0.0 & 0.0 & 0.0 & 0.1 & 0.0 & 2.7 & 1.3 & 0.0 & 0.0 \\
\hline Norway & 29.1 & 208.4 & 114.8 & 56.6 & 19.9 & 222.7 & 224.3 & 134.0 & 48.6 & 0.0 \\
\hline Switzerland & 6.6 & 131.6 & 77.7 & 100.9 & 30.5 & 168.2 & 111.3 & 106.8 & 21.2 & 0.0 \\
\hline U.S. & 5.2 & 3.2 & 0.9 & 24.2 & 5.0 & 2.6 & 3.3 & 16.7 & 8.7 & 1.6 \\
\hline \multicolumn{11}{|c|}{ Tariff equivalents of subsidies, 2001-03 } \\
\hline Australia & 6.8 & 16.1 & 18.5 & 19.5 & 0.0 & 20.8 & 5.6 & 17.4 & 5.8 & 20.1 \\
\hline Canada & 0.0 & 19.1 & 11.7 & 0.0 & -1.3 & 9.3 & 4.8 & 2.7 & 13.2 & 0.0 \\
\hline EU-15 & 12.8 & 20.4 & 20.7 & 4.6 & 2.4 & 18.7 & 10.3 & 13.7 & 14.3 & 0.0 \\
\hline Japan & 13.8 & 4.1 & 3.8 & 2.4 & 1.6 & 3.5 & 0.6 & 6.9 & 16.1 & 0.0 \\
\hline New Zealand & 0.0 & 0.0 & 0.0 & 0.0 & 0.0 & 5.8 & 5.3 & 5.7 & 0.0 & 0.0 \\
\hline Norway & 0.0 & 9.5 & 19.5 & 0.0 & 0.0 & 19.3 & 2.4 & 20.7 & 0.0 & 21.5 \\
\hline Switzerland & 0.0 & 11.3 & 12.2 & 6.3 & 0.0 & 13.7 & 6.2 & 20.3 & 16.4 & 0.0 \\
\hline U.S. & 20.5 & 21.0 & 20.1 & 4.8 & 13.0 & 7.2 & 9.0 & 11.9 & 20.5 & 4.8 \\
\hline \multicolumn{11}{|c|}{ Tariffs \& subsidies combined } \\
\hline Australia & 6.8 & 16.1 & 18.5 & 31.5 & 0.8 & 20.8 & 6.4 & 18.5 & 6.6 & 20.3 \\
\hline Canada & 0.0 & 22.1 & 12.0 & 4.5 & 0.5 & 18.5 & 46.1 & 103.1 & 13.2 & 0.0 \\
\hline EU-15 & 137.8 & 21.2 & 41.5 & 99.2 & 22.0 & 108.6 & 27.2 & 57.0 & 14.3 & 0.0 \\
\hline Japan & 1023.1 & 227.3 & 58.9 & 234.8 & 23.4 & 43.1 & 37.3 & 95.0 & 18.0 & 1.2 \\
\hline New Zealand & 0.0 & 0.0 & 0.0 & 0.0 & 0.1 & 5.9 & 8.2 & 7.1 & 0.0 & 0.0 \\
\hline Norway & 29.1 & 237.8 & 156.7 & 56.6 & 19.9 & 284.9 & 232.2 & 182.3 & 48.6 & 21.5 \\
\hline Switzerland & 6.6 & 157.7 & 99.5 & 113.5 & 30.5 & 204.9 & 124.4 & 148.8 & 41.0 & 0.0 \\
\hline U.S. & 26.8 & 24.9 & 21.1 & 30.2 & 18.6 & 10.0 & 12.7 & 30.6 & 31.0 & 6.5 \\
\hline
\end{tabular}


Table 7. Aggregate protection in rich countries with respect to non-DAC countries, agriculture and all goods, uniform ad valorem equivalents

\begin{tabular}{|c|c|c|c|c|}
\hline & $\begin{array}{c}\text { Tariffs } \\
\text { (Variant 6), } 2001\end{array}$ & Subsidies, 2001-03 & $\begin{array}{c}\text { Tariffs and } \\
\text { subsidies com- } \\
\text { bined }\end{array}$ & $\begin{array}{l}\text { Memo: Cline (2004) } \\
\text { Aggregate Measure } \\
\text { of Protection }\end{array}$ \\
\hline \multicolumn{5}{|l|}{ Agriculture } \\
\hline Australia & 0.8 & 6.4 & 7.3 & \\
\hline Canada & 10.8 & 2.8 & 14.0 & 52.26 \\
\hline EU-15 & 34.4 & 7.7 & 45.7 & 46.37 \\
\hline Japan & 158.1 & 3.9 & 179.1 & 82.05 \\
\hline New Zealand & 0.4 & 1.1 & 1.5 & \\
\hline Norway & 89.4 & 3.9 & 99.8 & \\
\hline Switzerland & 50.9 & 4.5 & 60.1 & \\
\hline United States & 5.0 & 10.7 & 16.4 & 19.92 \\
\hline \multicolumn{5}{|l|}{ All goods } \\
\hline Australia & 4.4 & 1.1 & 5.4 & \\
\hline Canada & 3.9 & 0.7 & 4.7 & 10.68 \\
\hline EU-15 & 7.5 & 1.4 & 9.4 & 9.53 \\
\hline Japan & 26.9 & 2.5 & 32.6 & 15.55 \\
\hline New Zealand & 2.6 & 0.2 & 2.7 & \\
\hline Norway & 16.8 & 0.6 & 18.3 & \\
\hline Switzerland & 11.0 & 0.5 & 12.1 & \\
\hline United States & 2.8 & 1.4 & 4.3 & 4.01 \\
\hline
\end{tabular}

Note: "Agriculture" includes the GTAP 6.0 product categories that correspond approximately to the coverage of the OECD subsidy database: Animal products; Cattle, sheep; Cattle, sheep meat; Dairy products; Oil seeds; Other grains; Other meat; Paddy rice; Plant-based fibers; Processed rice; Sugar; Sugar cane; Vegetables, fruit; Wheat.

Given the evidence that rich-country agricultural subsidies are less important for developing countries than tariffs, why have they received so much public attention? Table 8 borrows an idea from the Catholic Agency for Overseas Development to suggest one reason. Leaving aside the trade effect, government payments to agriculture also consume government funds. Economists call that an opportunity cost. Activists call it unjust. The table shows total government payments to agriculture for 2003, including payments excluded above as non-distortionary, per head of the relevant kind of livestock. Livestock figures are from the U.N. Food and Agriculture Organization’s FAOSTAT database. Subsidies for cattle include those for milk, those for chicken include eggs, and those for sheep include wool. The final column shows Net Aid Transfers (Roodman 2006b) per poor person in developing countries, where "the poor" 
are the 2.7 billion people living on less that $\$ 2$ a day. ${ }^{8}$ The rich countries as a whole give $\$ 106$ in subsidies per cow, \$16 per sheep, \$10 per pig, and \$14.50 per poor person.

Table 8. Subsidies per rich-country animal and aid per poor person, 2003 (\$)

\begin{tabular}{lrrrrr} 
& \multicolumn{3}{c}{ Subsidies per head of livestock } & \multicolumn{2}{c}{$\begin{array}{c}\text { Net aid transfers per } \\
\text { poor person in de- } \\
\text { veloping countries }\end{array}$} \\
\cline { 2 - 6 } Australia & 18.37 & 0.41 & 7.12 & 1.12 & 0.44 \\
Canada & 92.19 & 0.46 & 17.34 & 0.00 & 0.71 \\
EU-15 & 200.09 & 0.36 & 10.52 & 35.45 & 11.03 \\
Japan & 160.64 & 0.23 & 5.17 & 0.00 & 2.20 \\
New Zealand & 2.55 & 0.47 & 0.44 & 0.05 & 0.06 \\
Norway & 964.98 & 0.85 & 51.50 & 91.07 & 0.75 \\
Switzerland & 985.87 & 2.63 & 140.35 & 15.74 & 0.46 \\
United States & 41.34 & 0.43 & 6.16 & 2.22 & 5.26 \\
\hline Total & 106.54 & 0.40 & 10.48 & 15.76 & 14.50
\end{tabular}

\section{Conclusion}

The methodology described here is not as sophisticated as the general equilibrium approach of Anderson and Neary and the intensely econometric techniques of Kee, Nicita, and Olarreaga. But within a relatively simple conceptual framework, using high-quality and detailed data from the MAcMap data set, it produces plausible results. Indeed, the results make more sense that those derived purely using MAcMap weights, which appear to introduce substantial endogeneity bias when aggregating across major product groups.

With respect to developing countries, New Zealand is least protective, followed by the United States, Canada, and Australia. EU barriers are about three times as high as those of the United States in agriculture, and twice as high overall. Non-EU members Norway and Switzerland use their policy freedom to

\footnotetext{
${ }^{8}$ Net Aid Transfers differs from the standard Net Overseas Development Assistance (ODA) in netting out interest payments received on ODA loans and cancellation of non-ODA loans.
} 
erect even higher barriers, and Japan's well-known barriers against rice rank it as most protective. Overall, agricultural tariffs—not the subsidies so frequently cited in the media—are the largest barrier to exports from developing countries. The public attention paid to export subsidies has also been quite disproportionate. In the EU-15, for example, export subsidies are only $6.3 \%$ of all subsidies, which in turn are responsible for only about $20 \%$ of protection in agriculture with respect to developing countries. In other words, export subsidies are responsible for only $1.3 \%$ of the overall protective effect in EU agriculture. What partly explains the attention to agricultural subsidies is their sheer cost, which rivals spending on foreign aid. 


\section{Appendix. Detailed tables}

Table A-1. MAcMap protection and weights with respect to non-DAC countries, and production weights, by importer and GTAP product group (\%)

\begin{tabular}{|c|c|c|c|c|c|c|}
\hline Country name & Product name & Tariffs $^{1}(\%)$ & $\begin{array}{c}\text { MAcMap } \\
\text { weight (\%) }\end{array}$ & $\begin{array}{l}\text { Production } \\
\text { weight (\%) }\end{array}$ & $\begin{array}{l}\text { Tariff equiva- } \\
\text { lent of subsi- } \\
\text { dies (\%) }\end{array}$ & $\begin{array}{l}\text { Tariffs \& sub- } \\
\text { sidies (\%) }\end{array}$ \\
\hline Australia & Beverages and tobacco products & 0.44 & 2.83 & 15.75 & 0.00 & 15.75 \\
\hline Australia & Sugar cane, sugar beet & 0.00 & 0.19 & 0.00 & 0.00 & 0.00 \\
\hline Australia & Bovine meat products & 0.09 & 0.89 & 0.00 & 20.76 & 20.76 \\
\hline Australia & Coal & 0.55 & 0.56 & 0.00 & 0.00 & 0.00 \\
\hline Australia & Chemical, rubber, plastic products & 6.15 & 9.33 & 3.56 & 0.00 & 3.56 \\
\hline Australia & Bovine cattle, sheep and goats, horses & 0.06 & 0.88 & 0.00 & 0.00 & 0.00 \\
\hline Australia & Electronic equipment & 19.88 & 6.20 & 0.96 & 0.00 & 0.96 \\
\hline Australia & Electricity & 0.09 & 2.56 & 0.00 & 0.00 & 0.00 \\
\hline Australia & Metal products & 1.86 & 2.87 & 5.46 & 0.00 & 5.46 \\
\hline Australia & Forestry & 0.21 & 0.86 & 0.18 & 0.00 & 0.18 \\
\hline Australia & Fishing & 0.22 & 0.97 & 0.20 & 0.00 & 0.20 \\
\hline Australia & Gas & 1.89 & 0.97 & 0.00 & 0.00 & 0.00 \\
\hline Australia & Gas manufacture, distribution & 0.00 & 0.15 & 5.00 & 0.00 & 5.00 \\
\hline Australia & Cereal grains nec & 0.10 & 0.78 & 0.00 & 18.48 & 18.48 \\
\hline Australia & Ferrous metals & 2.01 & 3.51 & 3.88 & 0.00 & 3.88 \\
\hline Australia & Leather products & 2.53 & 1.55 & 8.04 & 0.00 & 8.04 \\
\hline Australia & Wood products & 2.69 & 2.04 & 4.65 & 0.00 & 4.65 \\
\hline Australia & Dairy products & 0.08 & 0.83 & 0.92 & 17.44 & 18.52 \\
\hline Australia & Motor vehicles and parts & 4.87 & 3.63 & 13.86 & 0.00 & 13.86 \\
\hline Australia & Metals nec & 3.37 & 2.20 & 0.76 & 0.00 & 0.76 \\
\hline Australia & Mineral products nec & 1.11 & 4.07 & 3.91 & 0.00 & 3.91 \\
\hline Australia & Animal products nec & 0.21 & 2.37 & 0.00 & 0.00 & 0.00 \\
\hline Australia & Crops nec & 0.93 & 1.36 & 0.02 & 0.00 & 0.02 \\
\hline Australia & Food products nec & 2.66 & 4.70 & 1.84 & 0.00 & 1.84 \\
\hline Australia & Oil & 12.73 & 3.80 & 5.47 & 0.00 & 5.47 \\
\hline Australia & Machinery and equipment nec & 10.40 & 8.00 & 4.04 & 0.00 & 4.04 \\
\hline Australia & Manufactures nec & 3.78 & 2.85 & 2.74 & 0.00 & 2.74 \\
\hline Australia & Minerals nec & 1.46 & 1.88 & 0.20 & 0.00 & 0.20 \\
\hline Australia & Meat products nec & 0.32 & 1.33 & 0.75 & 5.61 & 6.40 \\
\hline Australia & Oil seeds & 0.23 & 0.59 & 0.81 & 5.79 & 6.65 \\
\hline Australia & Transport equipment nec & 1.79 & 1.64 & 1.92 & 0.00 & 1.92 \\
\hline Australia & Petroleum, coal products & 2.84 & 4.11 & 0.00 & 0.00 & 0.00 \\
\hline Australia & Processed rice & 0.05 & 1.13 & 0.00 & 6.79 & 6.79 \\
\hline Australia & Paddy rice & 0.01 & 0.87 & 0.00 & 6.79 & 6.79 \\
\hline Australia & Plant-based fibers & 0.08 & 0.34 & 0.00 & 0.00 & 0.00 \\
\hline Australia & Paper products, publishing & 1.09 & 3.10 & 3.09 & 0.00 & 3.09 \\
\hline Australia & Sugar & 0.15 & 0.76 & 10.05 & 19.52 & 31.53 \\
\hline Australia & Textiles & 4.97 & 5.05 & 15.05 & 0.00 & 15.05 \\
\hline Australia & Vegetables, fruit, nuts & 1.07 & 3.86 & 0.81 & 0.00 & 0.81 \\
\hline Australia & Vegetable oils and fats & 0.50 & 0.74 & 1.03 & 0.00 & 1.03 \\
\hline Australia & Wearing apparel & 6.43 & 2.66 & 22.18 & 0.00 & 22.18 \\
\hline Australia & Wheat & 0.05 & 0.79 & 0.00 & 16.11 & 16.11 \\
\hline Australia & Wool, silk-worm cocoons & 0.02 & 0.17 & 0.16 & 20.07 & 20.27 \\
\hline Canada & Beverages and tobacco products & 0.44 & 2.83 & 6.93 & 0.00 & 6.93 \\
\hline Canada & Sugar cane, sugar beet & 0.00 & 0.19 & 0.00 & 0.00 & 0.00 \\
\hline Canada & Bovine meat products & 0.09 & 0.89 & 8.40 & 9.34 & 18.53 \\
\hline Canada & Coal & 0.55 & 0.56 & 0.00 & 0.00 & 0.00 \\
\hline Canada & Chemical, rubber, plastic products & 6.15 & 9.33 & 1.41 & 0.00 & 1.41 \\
\hline Canada & Bovine cattle, sheep and goats, horses & 0.06 & 0.88 & 0.00 & 0.00 & 0.00 \\
\hline Canada & Electronic equipment & 19.88 & 6.20 & 0.13 & 0.00 & 0.13 \\
\hline
\end{tabular}




\begin{tabular}{|c|c|c|c|c|c|c|}
\hline Country name & Product name & Tariffs $^{1}(\%)$ & $\begin{array}{c}\text { MAcMap } \\
\text { weight (\%) }\end{array}$ & $\begin{array}{l}\text { Production } \\
\text { weight (\%) }\end{array}$ & $\begin{array}{l}\text { Tariff equiva- } \\
\text { lent of subsi- } \\
\text { dies (\%) } \\
\end{array}$ & $\begin{array}{c}\text { Tariffs \& sub- } \\
\text { sidies (\%) } \\
\end{array}$ \\
\hline Canada & Electricity & 0.09 & 2.56 & 0.00 & 0.00 & 0.00 \\
\hline Canada & Metal products & 1.86 & 2.87 & 2.28 & 0.00 & 2.28 \\
\hline Canada & Forestry & 0.21 & 0.86 & 0.26 & 0.00 & 0.26 \\
\hline Canada & Fishing & 0.22 & 0.97 & 0.33 & 0.00 & 0.33 \\
\hline Canada & Gas & 1.89 & 0.97 & 0.64 & 0.00 & 0.64 \\
\hline Canada & Gas manufacture, distribution & 0.00 & 0.15 & 5.93 & 0.00 & 5.93 \\
\hline Canada & Cereal grains nec & 0.10 & 0.78 & 0.32 & 11.67 & 12.04 \\
\hline Canada & Ferrous metals & 2.01 & 3.51 & 0.37 & 0.00 & 0.37 \\
\hline Canada & Leather products & 2.53 & 1.55 & 8.30 & 0.00 & 8.30 \\
\hline Canada & Wood products & 2.69 & 2.04 & 2.02 & 0.00 & 2.02 \\
\hline Canada & Dairy products & 0.08 & 0.83 & 97.69 & 2.75 & 103.12 \\
\hline Canada & Motor vehicles and parts & 4.87 & 3.63 & 3.36 & 0.00 & 3.36 \\
\hline Canada & Metals nec & 3.37 & 2.20 & 0.05 & 0.00 & 0.05 \\
\hline Canada & Mineral products nec & 1.11 & 4.07 & 1.00 & 0.00 & 1.00 \\
\hline Canada & Animal products nec & 0.21 & 2.37 & 6.45 & 0.00 & 6.45 \\
\hline Canada & Crops nec & 0.93 & 1.36 & 0.47 & 0.00 & 0.47 \\
\hline Canada & Food products nec & 2.66 & 4.70 & 4.38 & 0.00 & 4.38 \\
\hline Canada & Oil & 12.73 & 3.80 & 0.00 & 0.00 & 0.00 \\
\hline Canada & Machinery and equipment nec & 10.40 & 8.00 & 1.09 & 0.00 & 1.09 \\
\hline Canada & Manufactures nec & 3.78 & 2.85 & 1.42 & 0.00 & 1.42 \\
\hline Canada & Minerals nec & 1.46 & 1.88 & 0.00 & 0.00 & 0.00 \\
\hline Canada & Meat products nec & 0.32 & 1.33 & 39.48 & 4.76 & 46.11 \\
\hline Canada & Oil seeds & 0.23 & 0.59 & 0.00 & 13.20 & 13.20 \\
\hline Canada & Transport equipment nec & 1.79 & 1.64 & 7.61 & 0.00 & 7.61 \\
\hline Canada & Petroleum, coal products & 2.84 & 4.11 & 0.27 & 0.00 & 0.27 \\
\hline Canada & Processed rice & 0.05 & 1.13 & 0.00 & 0.00 & 0.00 \\
\hline Canada & Paddy rice & 0.01 & 0.87 & 0.00 & 0.00 & 0.00 \\
\hline Canada & Plant-based fibers & 0.08 & 0.34 & 0.00 & 0.00 & 0.00 \\
\hline Canada & Paper products, publishing & 1.09 & 3.10 & 0.08 & 0.00 & 0.08 \\
\hline Canada & Sugar & 0.15 & 0.76 & 4.46 & 0.00 & 4.46 \\
\hline Canada & Textiles & 4.97 & 5.05 & 11.41 & 0.00 & 11.41 \\
\hline Canada & Vegetables, fruit, nuts & 1.07 & 3.86 & 1.76 & -1.26 & 0.48 \\
\hline Canada & Vegetable oils and fats & 0.50 & 0.74 & 2.24 & 0.00 & 2.24 \\
\hline Canada & Wearing apparel & 6.43 & 2.66 & 15.31 & 0.00 & 15.31 \\
\hline Canada & Wheat & 0.05 & 0.79 & 2.57 & 19.09 & 22.15 \\
\hline Canada & Wool, silk-worm cocoons & 0.02 & 0.17 & 0.00 & 0.00 & 0.00 \\
\hline EU-15 & Beverages and tobacco products & 0.44 & 2.83 & 10.54 & 0.00 & 10.54 \\
\hline EU-15 & Sugar cane, sugar beet & 0.00 & 0.19 & 71.85 & 0.00 & 71.85 \\
\hline EU-15 & Bovine meat products & 0.09 & 0.89 & 75.79 & 18.66 & 108.58 \\
\hline EU-15 & Coal & 0.55 & 0.56 & 0.00 & 0.00 & 0.00 \\
\hline EU-15 & Chemical, rubber, plastic products & 6.15 & 9.33 & 1.32 & 0.00 & 1.32 \\
\hline EU-15 & Bovine cattle, sheep and goats, horses & 0.06 & 0.88 & 15.44 & 0.00 & 15.44 \\
\hline EU-15 & Electronic equipment & 19.88 & 6.20 & 0.85 & 0.00 & 0.85 \\
\hline EU-15 & Electricity & 0.09 & 2.56 & 0.00 & 0.00 & 0.00 \\
\hline EU-15 & Metal products & 1.86 & 2.87 & 1.26 & 0.00 & 1.26 \\
\hline EU-15 & Forestry & 0.21 & 0.86 & 0.14 & 0.00 & 0.14 \\
\hline EU-15 & Fishing & 0.22 & 0.97 & 4.63 & 0.00 & 4.63 \\
\hline EU-15 & Gas & 1.89 & 0.97 & 0.00 & 0.00 & 0.00 \\
\hline EU-15 & Gas manufacture, distribution & 0.00 & 0.15 & 0.00 & 0.00 & 0.00 \\
\hline EU-15 & Cereal grains nec & 0.10 & 0.78 & 17.25 & 20.72 & 41.55 \\
\hline EU-15 & Ferrous metals & 2.01 & 3.51 & 3.38 & 0.00 & 3.38 \\
\hline EU-15 & Leather products & 2.53 & 1.55 & 5.62 & 0.00 & 5.62 \\
\hline EU-15 & Wood products & 2.69 & 2.04 & 0.41 & 0.00 & 0.41 \\
\hline EU-15 & Dairy products & 0.08 & 0.83 & 38.02 & 13.73 & 56.97 \\
\hline EU-15 & Motor vehicles and parts & 4.87 & 3.63 & 2.73 & 0.00 & 2.73 \\
\hline
\end{tabular}




\begin{tabular}{|c|c|c|c|c|c|c|}
\hline Country name & Product name & Tariffs $^{1}(\%)$ & $\begin{array}{c}\text { MAcMap } \\
\text { weight (\%) }\end{array}$ & $\begin{array}{l}\text { Production } \\
\text { weight (\%) }\end{array}$ & $\begin{array}{l}\text { Tariff equiva- } \\
\text { lent of subsi- } \\
\text { dies (\%) }\end{array}$ & $\begin{array}{c}\text { Tariffs \& sub- } \\
\text { sidies (\%) }\end{array}$ \\
\hline EU-15 & Metals nec & 3.37 & 2.20 & 1.61 & 0.00 & 1.61 \\
\hline EU-15 & Mineral products nec & 1.11 & 4.07 & 2.37 & 0.00 & 2.37 \\
\hline EU-15 & Animal products nec & 0.21 & 2.37 & 4.84 & 0.00 & 4.84 \\
\hline EU-15 & Crops nec & 0.93 & 1.36 & 2.14 & 0.00 & 2.14 \\
\hline EU-15 & Food products nec & 2.66 & 4.70 & 9.16 & 0.00 & 9.16 \\
\hline EU-15 & Oil & 12.73 & 3.80 & 0.00 & 0.00 & 0.00 \\
\hline EU-15 & Machinery and equipment nec & 10.40 & 8.00 & 0.45 & 0.00 & 0.45 \\
\hline EU-15 & Manufactures nec & 3.78 & 2.85 & 1.15 & 0.00 & 1.15 \\
\hline EU-15 & Minerals nec & 1.46 & 1.88 & 0.16 & 0.00 & 0.16 \\
\hline EU-15 & Meat products nec & 0.32 & 1.33 & 15.24 & 10.35 & 27.16 \\
\hline EU-15 & Oil seeds & 0.23 & 0.59 & 0.00 & 14.27 & 14.27 \\
\hline EU-15 & Transport equipment nec & 1.79 & 1.64 & 1.16 & 0.00 & 1.16 \\
\hline EU-15 & Petroleum, coal products & 2.84 & 4.11 & 0.63 & 0.00 & 0.63 \\
\hline EU-15 & Processed rice & 0.05 & 1.13 & 137.22 & 12.83 & 167.64 \\
\hline EU-15 & Paddy rice & 0.01 & 0.87 & 76.62 & 12.83 & 99.28 \\
\hline EU-15 & Plant-based fibers & 0.08 & 0.34 & 0.00 & 0.00 & 0.00 \\
\hline EU-15 & Paper products, publishing & 1.09 & 3.10 & 0.14 & 0.00 & 0.14 \\
\hline EU-15 & Sugar & 0.15 & 0.76 & 90.37 & 4.63 & 99.19 \\
\hline EU-15 & Textiles & 4.97 & 5.05 & 5.90 & 0.00 & 5.90 \\
\hline EU-15 & Vegetables, fruit, nuts & 1.07 & 3.86 & 19.12 & 2.40 & 21.98 \\
\hline EU-15 & Vegetable oils and fats & 0.50 & 0.74 & 4.92 & 0.00 & 4.92 \\
\hline EU-15 & Wearing apparel & 6.43 & 2.66 & 6.45 & 0.00 & 6.45 \\
\hline EU-15 & Wheat & 0.05 & 0.79 & 0.67 & 20.36 & 21.17 \\
\hline EU-15 & Wool, silk-worm cocoons & 0.02 & 0.17 & 0.00 & 0.00 & 0.00 \\
\hline Japan & Beverages and tobacco products & 0.44 & 2.83 & 16.39 & 0.00 & 16.39 \\
\hline Japan & Sugar cane, sugar beet & 0.00 & 0.19 & 0.00 & 0.00 & 0.00 \\
\hline Japan & Bovine meat products & 0.09 & 0.89 & 38.22 & 3.50 & 43.05 \\
\hline Japan & Coal & 0.55 & 0.56 & 0.01 & 0.00 & 0.01 \\
\hline Japan & Chemical, rubber, plastic products & 6.15 & 9.33 & 0.44 & 0.00 & 0.44 \\
\hline Japan & Bovine cattle, sheep and goats, horses & 0.06 & 0.88 & 53.60 & 0.00 & 53.60 \\
\hline Japan & Electronic equipment & 19.88 & 6.20 & 0.00 & 0.00 & 0.00 \\
\hline Japan & Electricity & 0.09 & 2.56 & 0.00 & 0.00 & 0.00 \\
\hline Japan & Metal products & 1.86 & 2.87 & 0.13 & 0.00 & 0.13 \\
\hline Japan & Forestry & 0.21 & 0.86 & 0.79 & 0.00 & 0.79 \\
\hline Japan & Fishing & 0.22 & 0.97 & 4.04 & 0.00 & 4.04 \\
\hline Japan & Gas & 1.89 & 0.97 & 2.60 & 0.00 & 2.60 \\
\hline Japan & Gas manufacture, distribution & 0.00 & 0.15 & 0.00 & 0.00 & 0.00 \\
\hline Japan & Cereal grains nec & 0.10 & 0.78 & 53.18 & 3.75 & 58.93 \\
\hline Japan & Ferrous metals & 2.01 & 3.51 & 0.39 & 0.00 & 0.39 \\
\hline Japan & Leather products & 2.53 & 1.55 & 14.55 & 0.00 & 14.55 \\
\hline Japan & Wood products & 2.69 & 2.04 & 0.64 & 0.00 & 0.64 \\
\hline Japan & Dairy products & 0.08 & 0.83 & 82.44 & 6.90 & 95.03 \\
\hline Japan & Motor vehicles and parts & 4.87 & 3.63 & 0.00 & 0.00 & 0.00 \\
\hline Japan & Metals nec & 3.37 & 2.20 & 0.37 & 0.00 & 0.37 \\
\hline Japan & Mineral products nec & 1.11 & 4.07 & 0.16 & 0.00 & 0.16 \\
\hline Japan & Animal products nec & 0.21 & 2.37 & 11.02 & 0.00 & 11.02 \\
\hline Japan & Crops nec & 0.93 & 1.36 & 1.27 & 0.00 & 1.27 \\
\hline Japan & Food products nec & 2.66 & 4.70 & 12.11 & 0.00 & 12.11 \\
\hline Japan & Oil & 12.73 & 3.80 & 0.00 & 0.00 & 0.00 \\
\hline Japan & Machinery and equipment nec & 10.40 & 8.00 & 0.04 & 0.00 & 0.04 \\
\hline Japan & Manufactures nec & 3.78 & 2.85 & 0.81 & 0.00 & 0.81 \\
\hline Japan & Minerals nec & 1.46 & 1.88 & 0.39 & 0.00 & 0.39 \\
\hline Japan & Meat products nec & 0.32 & 1.33 & 36.55 & 0.56 & 37.31 \\
\hline Japan & Oil seeds & 0.23 & 0.59 & 1.62 & 16.09 & 17.97 \\
\hline Japan & Transport equipment nec & 1.79 & 1.64 & 0.00 & 0.00 & 0.00 \\
\hline
\end{tabular}




\begin{tabular}{|c|c|c|c|c|c|c|}
\hline Country name & Product name & Tariffs $^{1}(\%)$ & $\begin{array}{c}\text { MAcMap } \\
\text { weight (\%) }\end{array}$ & $\begin{array}{l}\text { Production } \\
\text { weight (\%) }\end{array}$ & $\begin{array}{l}\text { Tariff equiva- } \\
\text { lent of subsi- } \\
\text { dies }(\%) \\
\end{array}$ & $\begin{array}{c}\text { Tariffs \& sub- } \\
\text { sidies (\%) }\end{array}$ \\
\hline Japan & Petroleum, coal products & 2.84 & 4.11 & 2.83 & 0.00 & 2.83 \\
\hline Japan & Processed rice & 0.05 & 1.13 & 919.46 & 13.82 & 1060.37 \\
\hline Japan & Paddy rice & 0.01 & 0.87 & 844.37 & 13.82 & 974.91 \\
\hline Japan & Plant-based fibers & 0.08 & 0.34 & 0.00 & 0.00 & 0.00 \\
\hline Japan & Paper products, publishing & 1.09 & 3.10 & 0.18 & 0.00 & 0.18 \\
\hline Japan & Sugar & 0.15 & 0.76 & 227.02 & 2.38 & 234.80 \\
\hline Japan & Textiles & 4.97 & 5.05 & 6.13 & 0.00 & 6.13 \\
\hline Japan & Vegetables, fruit, nuts & 1.07 & 3.86 & 21.41 & 1.65 & 23.41 \\
\hline Japan & Vegetable oils and fats & 0.50 & 0.74 & 4.83 & 0.00 & 4.83 \\
\hline Japan & Wearing apparel & 6.43 & 2.66 & 9.73 & 0.00 & 9.73 \\
\hline Japan & Wheat & 0.05 & 0.79 & 214.41 & 4.11 & 227.34 \\
\hline Japan & Wool, silk-worm cocoons & 0.02 & 0.17 & 1.15 & 0.00 & 1.15 \\
\hline New Zealand & Beverages and tobacco products & 0.44 & 2.90 & 16.30 & 0.00 & 16.30 \\
\hline New Zealand & Sugar cane, sugar beet & 0.00 & 0.20 & 0.00 & 0.00 & 0.00 \\
\hline New Zealand & Bovine meat products & 0.09 & 0.92 & 0.04 & 5.82 & 5.86 \\
\hline New Zealand & Coal & 0.55 & 0.57 & 0.00 & 0.00 & 0.00 \\
\hline New Zealand & Chemical, rubber, plastic products & 6.16 & 9.58 & 2.04 & 0.00 & 2.04 \\
\hline New Zealand & Bovine cattle, sheep and goats, horses & 0.06 & 0.90 & 0.00 & 0.00 & 0.00 \\
\hline New Zealand & Electronic equipment & 19.90 & 6.36 & 1.14 & 0.00 & 1.14 \\
\hline New Zealand & Metal products & 1.87 & 2.95 & 2.94 & 0.00 & 2.94 \\
\hline New Zealand & Forestry & 0.21 & 0.89 & 0.03 & 0.00 & 0.03 \\
\hline New Zealand & Fishing & 0.22 & 0.99 & 0.31 & 0.00 & 0.31 \\
\hline New Zealand & Gas & 1.89 & 1.00 & 0.00 & 0.00 & 0.00 \\
\hline New Zealand & Gas manufacture, distribution & 0.00 & 0.16 & 0.00 & 0.00 & 0.00 \\
\hline New Zealand & Cereal grains nec & 0.10 & 0.81 & 0.00 & 0.00 & 0.00 \\
\hline New Zealand & Ferrous metals & 2.01 & 3.60 & 1.91 & 0.00 & 1.91 \\
\hline New Zealand & Leather products & 2.53 & 1.59 & 6.17 & 0.00 & 6.17 \\
\hline New Zealand & Wood products & 2.70 & 2.09 & 3.42 & 0.00 & 3.42 \\
\hline New Zealand & Dairy products & 0.08 & 0.85 & 1.33 & 5.71 & 7.12 \\
\hline New Zealand & Motor vehicles and parts & 4.88 & 3.73 & 6.23 & 0.00 & 6.23 \\
\hline New Zealand & Metals nec & 3.37 & 2.26 & 0.44 & 0.00 & 0.44 \\
\hline New Zealand & Mineral products nec & 1.11 & 4.18 & 2.27 & 0.00 & 2.27 \\
\hline New Zealand & Animal products nec & 0.21 & 2.43 & 0.36 & 0.00 & 0.36 \\
\hline New Zealand & Crops nec & 0.93 & 1.40 & 0.45 & 0.00 & 0.45 \\
\hline New Zealand & Food products nec & 2.66 & 4.83 & 1.56 & 0.00 & 1.56 \\
\hline New Zealand & Oil & 12.74 & 3.90 & 0.00 & 0.00 & 0.00 \\
\hline New Zealand & Machinery and equipment nec & 10.40 & 8.21 & 2.53 & 0.00 & 2.53 \\
\hline New Zealand & Manufactures nec & 3.78 & 2.92 & 2.41 & 0.00 & 2.41 \\
\hline New Zealand & Minerals nec & 1.46 & 1.92 & 0.00 & 0.00 & 0.00 \\
\hline New Zealand & Meat products nec & 0.32 & 1.36 & 2.71 & 5.31 & 8.16 \\
\hline New Zealand & Oil seeds & 0.23 & 0.60 & 0.00 & 0.00 & 0.00 \\
\hline New Zealand & Transport equipment nec & 1.80 & 1.68 & 1.35 & 0.00 & 1.35 \\
\hline New Zealand & Petroleum, coal products & 2.85 & 4.21 & 0.68 & 0.00 & 0.68 \\
\hline New Zealand & Processed rice & 0.05 & 1.16 & 0.00 & 0.00 & 0.00 \\
\hline New Zealand & Paddy rice & 0.01 & 0.90 & 0.00 & 0.00 & 0.00 \\
\hline New Zealand & Plant-based fibers & 0.08 & 0.35 & 0.00 & 0.00 & 0.00 \\
\hline New Zealand & Paper products, publishing & 1.09 & 3.19 & 1.60 & 0.00 & 1.60 \\
\hline New Zealand & Sugar & 0.15 & 0.78 & 0.00 & 0.00 & 0.00 \\
\hline New Zealand & Textiles & 4.97 & 5.18 & 5.93 & 0.00 & 5.93 \\
\hline New Zealand & Vegetables, fruit, nuts & 1.07 & 3.96 & 0.07 & 0.00 & 0.07 \\
\hline New Zealand & Vegetable oils and fats & 0.50 & 0.76 & 0.40 & 0.00 & 0.40 \\
\hline New Zealand & Wearing apparel & 6.43 & 2.73 & 11.58 & 0.00 & 11.58 \\
\hline New Zealand & Wheat & 0.05 & 0.81 & 0.00 & 0.00 & 0.00 \\
\hline New Zealand & Wool, silk-worm cocoons & 0.02 & 0.17 & 0.00 & 0.00 & 0.00 \\
\hline Norway & Beverages and tobacco products & 0.44 & 2.83 & 22.33 & 0.00 & 22.33 \\
\hline
\end{tabular}




\begin{tabular}{|c|c|c|c|c|c|c|}
\hline Country name & Product name & Tariffs $^{1}(\%)$ & $\begin{array}{c}\text { MAcMap } \\
\text { weight (\%) }\end{array}$ & $\begin{array}{l}\text { Production } \\
\text { weight (\%) }\end{array}$ & $\begin{array}{l}\text { Tariff equiva- } \\
\text { lent of subsi- } \\
\text { dies (\%) } \\
\end{array}$ & $\begin{array}{c}\text { Tariffs \& sub- } \\
\text { sidies (\%) }\end{array}$ \\
\hline Norway & Sugar cane, sugar beet & 0.00 & 0.19 & 137.51 & 0.00 & 137.51 \\
\hline Norway & Bovine meat products & 0.09 & 0.89 & 222.73 & 19.28 & 284.94 \\
\hline Norway & Coal & 0.55 & 0.56 & 0.00 & 0.00 & 0.00 \\
\hline Norway & Chemical, rubber, plastic products & 6.15 & 9.33 & 0.10 & 0.00 & 0.10 \\
\hline Norway & Bovine cattle, sheep and goats, horses & 0.06 & 0.88 & 106.20 & 0.00 & 106.20 \\
\hline Norway & Electronic equipment & 19.88 & 6.20 & 0.00 & 0.00 & 0.00 \\
\hline Norway & Electricity & 0.09 & 2.56 & 0.00 & 0.00 & 0.00 \\
\hline Norway & Metal products & 1.86 & 2.87 & 0.03 & 0.00 & 0.03 \\
\hline Norway & Forestry & 0.21 & 0.86 & 0.46 & 0.00 & 0.46 \\
\hline Norway & Fishing & 0.22 & 0.97 & 0.36 & 0.00 & 0.36 \\
\hline Norway & Gas & 1.89 & 0.97 & 0.00 & 0.00 & 0.00 \\
\hline Norway & Gas manufacture, distribution & 0.00 & 0.15 & 0.00 & 0.00 & 0.00 \\
\hline Norway & Cereal grains nec & 0.10 & 0.78 & 114.80 & 19.53 & 156.75 \\
\hline Norway & Ferrous metals & 2.01 & 3.51 & 0.00 & 0.00 & 0.00 \\
\hline Norway & Leather products & 2.53 & 1.55 & 2.70 & 0.00 & 2.70 \\
\hline Norway & Wood products & 2.69 & 2.04 & 0.01 & 0.00 & 0.01 \\
\hline Norway & Dairy products & 0.08 & 0.83 & 134.00 & 20.65 & 182.33 \\
\hline Norway & Motor vehicles and parts & 4.87 & 3.63 & 0.00 & 0.00 & 0.00 \\
\hline Norway & Metals nec & 3.37 & 2.20 & 0.02 & 0.00 & 0.02 \\
\hline Norway & Mineral products nec & 1.11 & 4.07 & 0.00 & 0.00 & 0.00 \\
\hline Norway & Animal products nec & 0.21 & 2.37 & 88.10 & 0.00 & 88.10 \\
\hline Norway & Crops nec & 0.93 & 1.36 & 9.49 & 0.00 & 9.49 \\
\hline Norway & Food products nec & 2.66 & 4.70 & 29.00 & 0.00 & 29.00 \\
\hline Norway & Oil & 12.73 & 3.80 & 0.00 & 0.00 & 0.00 \\
\hline Norway & Machinery and equipment nec & 10.40 & 8.00 & 0.01 & 0.00 & 0.01 \\
\hline Norway & Manufactures nec & 3.78 & 2.85 & 0.03 & 0.00 & 0.03 \\
\hline Norway & Minerals nec & 1.46 & 1.88 & 0.00 & 0.00 & 0.00 \\
\hline Norway & Meat products nec & 0.32 & 1.33 & 224.28 & 2.45 & 232.22 \\
\hline Norway & Oil seeds & 0.23 & 0.59 & 48.60 & 0.00 & 48.60 \\
\hline Norway & Transport equipment nec & 1.79 & 1.64 & 0.04 & 0.00 & 0.04 \\
\hline Norway & Petroleum, coal products & 2.84 & 4.11 & 0.00 & 0.00 & 0.00 \\
\hline Norway & Processed rice & 0.05 & 1.13 & 27.06 & 0.00 & 27.06 \\
\hline Norway & Paddy rice & 0.01 & 0.87 & 31.75 & 0.00 & 31.75 \\
\hline Norway & Plant-based fibers & 0.08 & 0.34 & 0.00 & 0.00 & 0.00 \\
\hline Norway & Paper products, publishing & 1.09 & 3.10 & 0.00 & 0.00 & 0.00 \\
\hline Norway & Sugar & 0.15 & 0.76 & 56.58 & 0.00 & 56.58 \\
\hline Norway & Textiles & 4.97 & 5.05 & 4.07 & 0.00 & 4.07 \\
\hline Norway & Vegetables, fruit, nuts & 1.07 & 3.86 & 19.95 & 0.00 & 19.95 \\
\hline Norway & Vegetable oils and fats & 0.50 & 0.74 & 49.05 & 0.00 & 49.05 \\
\hline Norway & Wearing apparel & 6.43 & 2.66 & 3.85 & 0.00 & 3.85 \\
\hline Norway & Wheat & 0.05 & 0.79 & 208.40 & 9.54 & 237.82 \\
\hline Norway & Wool, silk-worm cocoons & 0.02 & 0.17 & 0.00 & 21.53 & 21.53 \\
\hline Switzerland & Beverages and tobacco products & 0.44 & 2.83 & 16.22 & 0.00 & 16.22 \\
\hline Switzerland & Sugar cane, sugar beet & 0.00 & 0.19 & 7.32 & 0.00 & 7.32 \\
\hline Switzerland & Bovine meat products & 0.09 & 0.89 & 168.16 & 13.72 & 204.95 \\
\hline Switzerland & Coal & 0.55 & 0.56 & 0.49 & 0.00 & 0.49 \\
\hline Switzerland & Chemical, rubber, plastic products & 6.15 & 9.33 & 1.03 & 0.00 & 1.03 \\
\hline Switzerland & Bovine cattle, sheep and goats, horses & 0.06 & 0.88 & 4.10 & 0.00 & 4.10 \\
\hline Switzerland & Electronic equipment & 19.88 & 6.20 & 0.43 & 0.00 & 0.43 \\
\hline Switzerland & Electricity & 0.09 & 2.56 & 0.00 & 0.00 & 0.00 \\
\hline Switzerland & Metal products & 1.86 & 2.87 & 1.18 & 0.00 & 1.18 \\
\hline Switzerland & Forestry & 0.21 & 0.86 & 0.59 & 0.00 & 0.59 \\
\hline Switzerland & Fishing & 0.22 & 0.97 & 0.11 & 0.00 & 0.11 \\
\hline Switzerland & Gas & 1.89 & 0.97 & 0.00 & 0.00 & 0.00 \\
\hline Switzerland & Gas manufacture, distribution & 0.00 & 0.15 & 0.01 & 0.00 & 0.01 \\
\hline
\end{tabular}


Tariff equiva-

\begin{tabular}{|c|c|c|c|c|c|c|}
\hline Country name & Product name & $\operatorname{Tariffs}^{1}(\%)$ & $\begin{array}{c}\text { MAcMap } \\
\text { weight (\%) }\end{array}$ & $\begin{array}{l}\text { Production } \\
\text { weight (\%) }\end{array}$ & $\begin{array}{l}\text { lent of subsi- } \\
\text { dies (\%) }\end{array}$ & $\begin{array}{l}\text { Tariffs \& sub- } \\
\text { sidies (\%) } \\
\end{array}$ \\
\hline Switzerland & Cereal grains nec & 0.10 & 0.78 & 77.72 & 12.24 & 99.46 \\
\hline Switzerland & Ferrous metals & 2.01 & 3.51 & 0.95 & 0.00 & 0.95 \\
\hline Switzerland & Leather products & 2.53 & 1.55 & 1.06 & 0.00 & 1.06 \\
\hline Switzerland & Wood products & 2.69 & 2.04 & 1.37 & 0.00 & 1.37 \\
\hline Switzerland & Dairy products & 0.08 & 0.83 & 106.84 & 20.30 & 148.82 \\
\hline Switzerland & Motor vehicles and parts & 4.87 & 3.63 & 1.23 & 0.00 & 1.23 \\
\hline Switzerland & Metals nec & 3.37 & 2.20 & 0.70 & 0.00 & 0.70 \\
\hline Switzerland & Mineral products nec & 1.11 & 4.07 & 1.94 & 0.00 & 1.94 \\
\hline Switzerland & Animal products nec & 0.21 & 2.37 & 7.65 & 0.00 & 7.65 \\
\hline Switzerland & Crops nec & 0.93 & 1.36 & 8.18 & 0.00 & 8.18 \\
\hline Switzerland & Food products nec & 2.66 & 4.70 & 14.02 & 0.00 & 14.02 \\
\hline Switzerland & Oil & 12.73 & 3.80 & 0.00 & 0.00 & 0.00 \\
\hline Switzerland & Machinery and equipment nec & 10.40 & 8.00 & 0.74 & 0.00 & 0.74 \\
\hline Switzerland & Manufactures nec & 3.78 & 2.85 & 22.70 & 0.00 & 22.70 \\
\hline Switzerland & Minerals nec & 1.46 & 1.88 & 3.58 & 0.00 & 3.58 \\
\hline Switzerland & Meat products nec & 0.32 & 1.33 & 111.32 & 6.19 & 124.40 \\
\hline Switzerland & Oil seeds & 0.23 & 0.59 & 21.20 & 16.38 & 41.04 \\
\hline Switzerland & Transport equipment nec & 1.79 & 1.64 & 0.72 & 0.00 & 0.72 \\
\hline Switzerland & Petroleum, coal products & 2.84 & 4.11 & 0.02 & 0.00 & 0.02 \\
\hline Switzerland & Processed rice & 0.05 & 1.13 & 7.11 & 0.00 & 7.11 \\
\hline Switzerland & Paddy rice & 0.01 & 0.87 & 5.84 & 0.00 & 5.84 \\
\hline Switzerland & Plant-based fibers & 0.08 & 0.34 & 0.00 & 0.00 & 0.00 \\
\hline Switzerland & Paper products, publishing & 1.09 & 3.10 & 2.51 & 0.00 & 2.51 \\
\hline Switzerland & Sugar & 0.15 & 0.76 & 100.89 & 6.28 & 113.52 \\
\hline Switzerland & Textiles & 4.97 & 5.05 & 5.25 & 0.00 & 5.25 \\
\hline Switzerland & Vegetables, fruit, nuts & 1.07 & 3.86 & 30.55 & 0.00 & 30.55 \\
\hline Switzerland & Vegetable oils and fats & 0.50 & 0.74 & 26.55 & 0.00 & 26.55 \\
\hline Switzerland & Wearing apparel & 6.43 & 2.66 & 4.55 & 0.00 & 4.55 \\
\hline Switzerland & Wheat & 0.05 & 0.79 & 131.60 & 11.28 & 157.73 \\
\hline Switzerland & Wool, silk-worm cocoons & 0.02 & 0.17 & 0.00 & 0.00 & 0.00 \\
\hline United States & Beverages and tobacco products & 0.44 & 2.83 & 2.67 & 0.00 & 2.67 \\
\hline United States & Sugar cane, sugar beet & 0.00 & 0.19 & 0.25 & 0.00 & 0.25 \\
\hline United States & Bovine meat products & 0.09 & 0.89 & 2.59 & 7.20 & 9.98 \\
\hline United States & Coal & 0.55 & 0.56 & 0.00 & 0.00 & 0.00 \\
\hline United States & Chemical, rubber, plastic products & 6.15 & 9.33 & 2.15 & 0.00 & 2.15 \\
\hline United States & Bovine cattle, sheep and goats, horses & 0.06 & 0.88 & 0.11 & 0.00 & 0.11 \\
\hline United States & Electronic equipment & 19.88 & 6.20 & 0.43 & 0.00 & 0.43 \\
\hline United States & Electricity & 0.09 & 2.56 & 0.00 & 0.00 & 0.00 \\
\hline United States & Metal products & 1.86 & 2.87 & 1.75 & 0.00 & 1.75 \\
\hline United States & Forestry & 0.21 & 0.86 & 0.16 & 0.00 & 0.16 \\
\hline United States & Fishing & 0.22 & 0.97 & 0.28 & 0.00 & 0.28 \\
\hline United States & Gas & 1.89 & 0.97 & 0.00 & 0.00 & 0.00 \\
\hline United States & Gas manufacture, distribution & 0.00 & 0.15 & 0.00 & 0.00 & 0.00 \\
\hline United States & Cereal grains nec & 0.10 & 0.78 & 0.88 & 20.07 & 21.13 \\
\hline United States & Ferrous metals & 2.01 & 3.51 & 1.21 & 0.00 & 1.21 \\
\hline United States & Leather products & 2.53 & 1.55 & 9.80 & 0.00 & 9.80 \\
\hline United States & Wood products & 2.69 & 2.04 & 0.61 & 0.00 & 0.61 \\
\hline United States & Dairy products & 0.08 & 0.83 & 16.67 & 11.90 & 30.55 \\
\hline United States & Motor vehicles and parts & 4.87 & 3.63 & 2.28 & 0.00 & 2.28 \\
\hline United States & Metals nec & 3.37 & 2.20 & 1.01 & 0.00 & 1.01 \\
\hline United States & Mineral products nec & 1.11 & 4.07 & 3.59 & 0.00 & 3.59 \\
\hline United States & Animal products nec & 0.21 & 2.37 & 0.44 & 0.00 & 0.44 \\
\hline United States & Crops nec & 0.93 & 1.36 & 2.71 & 0.00 & 2.71 \\
\hline United States & Food products nec & 2.66 & 4.70 & 3.13 & 0.00 & 3.13 \\
\hline United States & Oil & 12.73 & 3.80 & 0.00 & 0.00 & 0.00 \\
\hline
\end{tabular}




\begin{tabular}{|c|c|c|c|c|c|c|}
\hline Country name & Product name & Tariffs $^{1}(\%)$ & $\begin{array}{c}\text { MAcMap } \\
\text { weight (\%) }\end{array}$ & $\begin{array}{l}\text { Production } \\
\text { weight (\%) }\end{array}$ & $\begin{array}{l}\text { Tariff equiva- } \\
\text { lent of subsi- } \\
\text { dies }(\%)\end{array}$ & $\begin{array}{l}\text { Tariffs \& sub- } \\
\text { sidies (\%) }\end{array}$ \\
\hline United States & Machinery and equipment nec & 10.40 & 8.00 & 1.38 & 0.00 & 1.38 \\
\hline United States & Manufactures nec & 3.78 & 2.85 & 1.60 & 0.00 & 1.60 \\
\hline United States & Minerals nec & 1.46 & 1.88 & 0.09 & 0.00 & 0.09 \\
\hline United States & Meat products nec & 0.32 & 1.33 & 3.35 & 9.03 & 12.68 \\
\hline United States & Oil seeds & 0.23 & 0.59 & 8.71 & 20.48 & 30.97 \\
\hline United States & Transport equipment nec & 1.79 & 1.64 & 1.05 & 0.00 & 1.05 \\
\hline United States & Petroleum, coal products & 2.84 & 4.11 & 1.02 & 0.00 & 1.02 \\
\hline United States & Processed rice & 0.05 & 1.13 & 5.21 & 20.50 & 26.78 \\
\hline United States & Paddy rice & 0.01 & 0.87 & 5.19 & 20.50 & 26.76 \\
\hline United States & Plant-based fibers & 0.08 & 0.34 & 0.99 & 0.00 & 0.99 \\
\hline United States & Paper products, publishing & 1.09 & 3.10 & 0.18 & 0.00 & 0.18 \\
\hline United States & Sugar & 0.15 & 0.76 & 24.22 & 4.78 & 30.16 \\
\hline United States & Textiles & 4.97 & 5.05 & 9.81 & 0.00 & 9.81 \\
\hline United States & Vegetables, fruit, nuts & 1.07 & 3.86 & 4.98 & 12.98 & 18.61 \\
\hline United States & Vegetable oils and fats & 0.50 & 0.74 & 2.98 & 0.00 & 2.98 \\
\hline United States & Wearing apparel & 6.43 & 2.66 & 11.27 & 0.00 & 11.27 \\
\hline United States & Wheat & 0.05 & 0.79 & 3.19 & 21.05 & 24.91 \\
\hline United States & Wool, silk-worm cocoons & 0.02 & 0.17 & 1.62 & 4.82 & 6.51 \\
\hline
\end{tabular}

${ }^{1}$ MAcMap values aggregated across HS 6 lines by MAcMap weights and across exporters by exporter's GDP. 
Table A-2. Computation of ad valorem tariff equivalents of agricultural subsidies by importer and product group

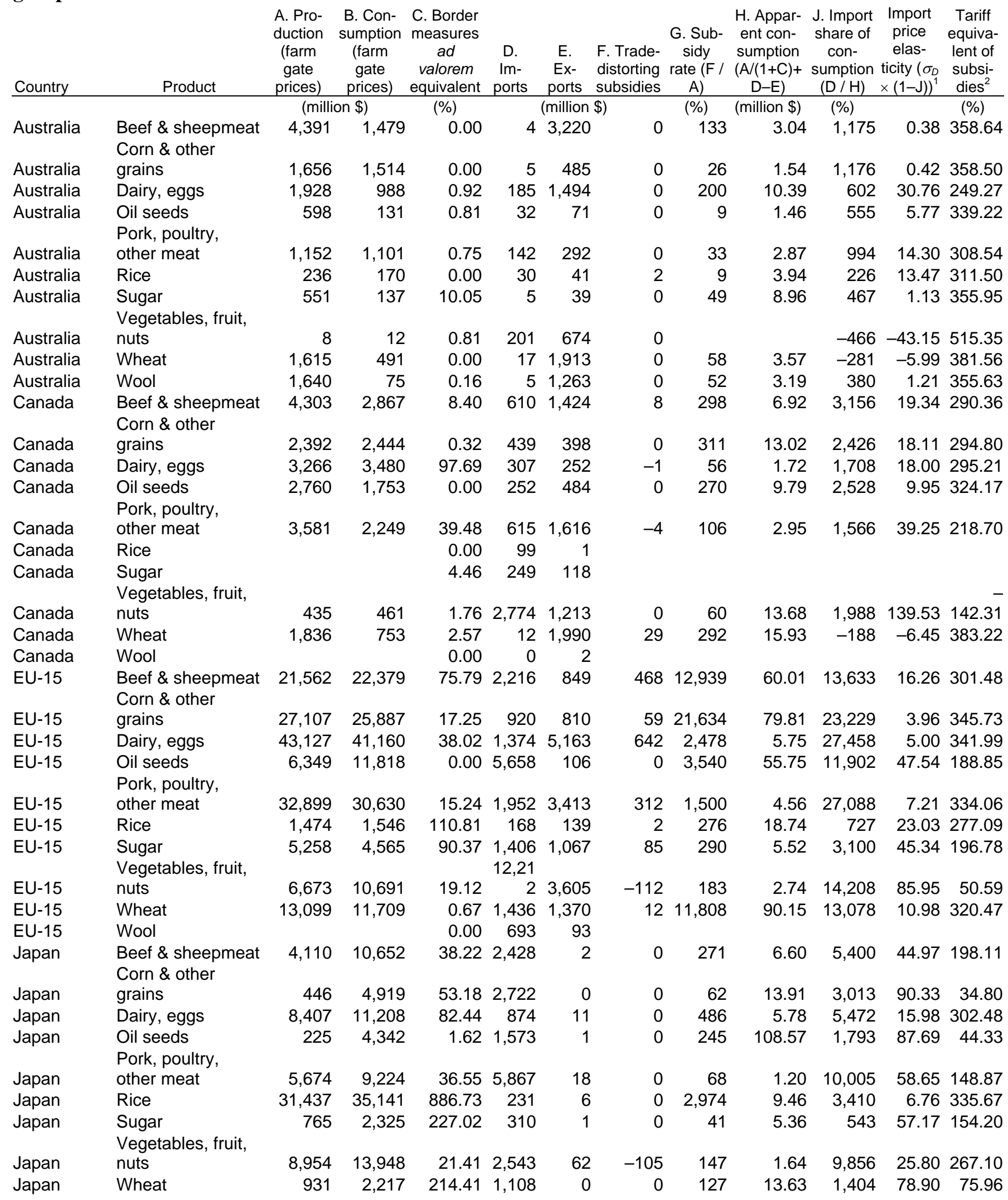




\begin{tabular}{|c|c|c|c|c|c|c|c|c|c|c|c|c|}
\hline Country & Product & $\begin{array}{l}\text { A. Pro- } \\
\text { duction } \\
\text { (farm } \\
\text { gate } \\
\text { prices) }\end{array}$ & $\begin{array}{l}\text { B. Con- } \\
\text { sumption } \\
\text { (farm } \\
\text { gate } \\
\text { prices) } \\
\end{array}$ & $\begin{array}{l}\text { C. Border } \\
\text { measures } \\
\text { ad } \\
\text { valorem } \\
\text { equivalent }\end{array}$ & $\begin{array}{l}\text { D. } \\
\text { Im- } \\
\text { ports }\end{array}$ & $\begin{array}{l}\text { E. } \\
\text { Ex- } \\
\text { ports }\end{array}$ & $\begin{array}{l}\text { F. Trade- } \\
\text { distorting } \\
\text { subsidies }\end{array}$ & $\begin{array}{l}\text { G. Sub- } \\
\text { sidy } \\
\text { rate (F / } \\
\text { A) } \\
\end{array}$ & $\begin{array}{l}\text { H. Appar- } \\
\text { ent con- } \\
\text { sumption } \\
(\mathrm{A} /(1+\mathrm{C})+ \\
\mathrm{D}-\mathrm{E}) \\
\end{array}$ & $\begin{array}{l}\text { J. Import } \\
\text { share of } \\
\text { con- } \\
\text { sumption } \\
(\mathrm{D} / \mathrm{H})\end{array}$ & $\begin{array}{l}\text { Import } \\
\text { price } \\
\text { elas- } \\
\text { ticity }\left(\sigma_{D}\right. \\
\times(1-J))^{1} \\
\end{array}$ & $\begin{array}{l}\text { Tariff } \\
\text { equiva- } \\
\text { lent of } \\
\text { subsi- } \\
\text { dies }^{2} \\
\end{array}$ \\
\hline Japan & Wool & & & 1.15 & 3 & 0 & & & & & & \\
\hline N. Zealand & $\begin{array}{l}\text { Beef \& sheepmeat } \\
\text { Corn \& other }\end{array}$ & 1,889 & 333 & 0.04 & 26 & 2,141 & 0 & 9 & 0.46 & -227 & -11.24 & 400.47 \\
\hline N. Zealand & grains & 133 & 146 & 0.00 & 8 & 1 & 0 & 0 & 0.00 & 140 & 5.96 & 338.53 \\
\hline 1. Zealand & Dairy, eggs & 2,526 & 316 & 1.33 & 37 & 2,797 & 0 & 13 & 0.52 & -266 & -14.07 & 410.66 \\
\hline N. Zealand & $\begin{array}{l}\text { Oil seeds } \\
\text { Pork, poultry, }\end{array}$ & & & 0.00 & 5 & 1 & & & & & & \\
\hline N. Zealand & other meat & 220 & 237 & 2.71 & 56 & 167 & 4 & 6 & 2.62 & 103 & 54.22 & 164.82 \\
\hline 1. Zealand & Rice & & & 0.00 & 19 & 0 & & & & & & \\
\hline N. Zealand & Sugar & & & 0.00 & 52 & 8 & & & & & & \\
\hline 1. Zealand & $\begin{array}{l}\text { Vegetables, fruit, } \\
\text { nuts }\end{array}$ & & & 0.07 & 136 & 685 & & & & & & \\
\hline V. Zealand & Wheat & 48 & 78 & 0.00 & 51 & 0 & 0 & 0 & 0.00 & 99 & 51.21 & 175.64 \\
\hline N. Zealand & Wool & 316 & 45 & 0.00 & 0 & 130 & 0 & 0 & 0.00 & 186 & 0.14 & 359.50 \\
\hline Norway & $\begin{array}{l}\text { Beef \& sheepmeat } \\
\text { Corn \& other }\end{array}$ & 401 & 428 & 222.73 & 33 & 3 & -23 & 382 & 95.15 & 155 & 21.35 & 283.14 \\
\hline lorway & grain & 402 & 406 & 114.80 & 16 & 0 & -1 & 222 & 55.12 & 203 & 7.82 & 331.86 \\
\hline Norway & Dairy, eggs & 742 & 679 & 134.00 & 40 & 84 & -8 & 607 & 81.76 & 274 & 14.74 & 306.92 \\
\hline Norway & $\begin{array}{l}\text { Oil seeds } \\
\text { Pork, poultry }\end{array}$ & & & 48.60 & 114 & 0 & & & & & & \\
\hline Vorway & other $r$ & 368 & 376 & 224.28 & 133 & 56 & -33 & 12 & 3.30 & 190 & 69.85 & 108.55 \\
\hline Norway & Rice & & & 29.11 & 11 & 0 & & & & & & \\
\hline Norway & $\begin{array}{l}\text { Sugar } \\
\text { Vegetable }\end{array}$ & & & 56.58 & 62 & 0 & & & & & & \\
\hline lorway & no & & & 19.95 & 440 & 3 & & & & & & \\
\hline lorway & Wheat & 76 & 104 & 208.40 & 44 & 0 & -1 & 26 & 34.25 & 69 & 64.19 & 128.90 \\
\hline Norway & Wool & 17 & 6 & 0.00 & 1 & 5 & 0 & 48 & 282.98 & 13 & 4.16 & 345.02 \\
\hline Switzerland & $\begin{array}{l}\text { Beef \& sheepmeat } \\
\text { Corn \& other }\end{array}$ & 705 & 784 & 168.16 & 149 & 4 & -5 & 294 & 41.66 & 408 & 36.45 & 228.79 \\
\hline Switzerland & grains & 122 & 233 & 77.72 & 41 & 1 & 0 & 41 & 33.40 & 108 & 37.46 & 225.16 \\
\hline Switz & 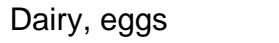 & 1,677 & 1,715 & 10 & 240 & 394 & 25 & 816 & 48. & 656 & 36.53 & 228.50 \\
\hline Switzerland & $\begin{array}{l}\text { Oil s } \\
\text { Pork }\end{array}$ & 39 & 221 & 21.20 & 29 & 1 & 0 & 31 & 79.82 & 61 & 48.17 & 186.59 \\
\hline $\begin{array}{l}\text { Switzerland } \\
\text { Switzerland }\end{array}$ & $\begin{array}{l}\text { other } \\
\text { Rice }\end{array}$ & 826 & 959 & $\begin{array}{r}111.32 \\
6.56\end{array}$ & $\begin{array}{r}315 \\
22\end{array}$ & $\begin{array}{r}17 \\
0\end{array}$ & -47 & 107 & 12.95 & 689 & 45.71 & 195.45 \\
\hline Switzerland & $\begin{array}{l}\text { Sugar } \\
\text { Vegetables, fruit, }\end{array}$ & 96 & 200 & 100.89 & 64 & 3 & 0 & 16 & 16.22 & 109 & 59.23 & 146.77 \\
\hline Swit & nuts & & & 3 & 910 & 4 & & & & & & \\
\hline Switz & n & 171 & 335 & 131.60 & 64 & 0 & 0 & 59 & 34.60 & 137 & 46.41 & 192.91 \\
\hline Switzerland & Wool & & & 0.00 & 1 & 1 & & & & & & \\
\hline U.S. & $\begin{array}{l}\text { Beef \& sheepmeat } \\
\text { Corn \& other }\end{array}$ & 33,463 & 35,915 & 2.59 & 2,984 & 3,849 & 0 & 1,080 & 3.23 & 31,753 & 9.40 & 326.17 \\
\hline U.S. & g & 4,958 & 20,275 & 88 & 467 & 5,790 & 0 & 97 & 20.83 & ,417 & 2.41 & 351.34 \\
\hline U.S. & Dairy, eggs & 27,022 & 26,744 & 16.67 & 1,477 & 761 & 0 & 1,565 & 5.79 & 23,877 & 6.19 & 337.73 \\
\hline U.S. & $\begin{array}{l}\text { Oil seeds } \\
\text { Pork, poultry }\end{array}$ & 15,280 & 9,822 & 8.71 & 228 & 7,149 & 0 & 3,190 & 20.88 & 7,135 & 3.20 & 348.48 \\
\hline U.S. & 0 & 27,270 & 24,330 & 3.35 & 1,583 & 3,871 & 2 & 861 & 3.16 & 24,100 & 6.57 & 336.35 \\
\hline U.S. & Rice & 2,146 & 1,261 & 5.20 & 197 & 534 & 0 & 1,515 & 70.58 & 1,703 & 11.55 & 318.43 \\
\hline U.S. & $\begin{array}{l}\text { Sugar } \\
\text { Vegetables, fruit, }\end{array}$ & 2,115 & 3,581 & 24.22 & 810 & 98 & -8 & 144 & 6.82 & 2,415 & 33.56 & 239.19 \\
\hline U.S. & nuts & 15,214 & 9,852 & 4.98 & 8,179 & 6,713 & 0 & 3,272 & 21.51 & 15,957 & 51.25 & 175.49 \\
\hline U.S. & Wheat & 6,391 & 3,885 & 3.19 & 213 & 3,804 & 0 & 2,161 & 33.81 & 2,603 & 8.19 & 330.50 \\
\hline U.S. & Wool & 21 & 23 & 1.62 & 24 & 18 & 0 & 1 & 2.57 & 28 & 87.46 & 45.13 \\
\hline
\end{tabular}




\section{References}

Anderson, James E., and J. Peter Neary, 1994, “Measuring the Restrictiveness of Trade Policy,” World Bank Economic Review, vol. 8, pp.151-69.

__ 1996, “A New Approach to Evaluating Trade Policy,” Review of Economic Studies 63 (1), pp. $107-25$.

—_, 2003. “The Mercantilist Index of Trade Policy,” International Economic Review 44 (2), pp. 62749.

Basevi, Giorgio, “Aggregation Problems in the Measurement of Effective Protection,” in Herbert G. Grubel and Harry G. Johnson, Effective Tariff Protection (Geneva: General Agreement on Tariffs and Trade and Graduate Institute of International Studies, 1971), pp. 115-34.

Bouët, Antoine, et al., 2004, “Computing an exhaustive and consistent, ad-valorem equivalent measure of applied protection: a detailed description of MAcMap-HS6 methodology,” 2nd ed., Paris, Centre d'Etudes Prospectives et d'Informations Internationales, June.

Cline, William R., 2002, “An Index of Industrial Country Trade Policy toward Developing Countries,” Working Paper 14, Center for Global Development, Washington, DC, October.

—_, 2004, Trade Policy and Global Poverty, Center for Global Development and Institute for International Economics, Washington, DC.

Cooper, Richard N., “Tariff Dispersion and Trade Negotiations,” Journal of Political Economy 72 (6), pp. 597-603.

Corden, Warner M., “The Effective Protection Rate, the Uniform Tariff Equivalent and the Average Tariff,” Economic Record, June 1966. 
Dimaranan, Betina V., and Robert A. McDougall, eds., 2002, Global Trade, Assistance, and Production: The GTAP5 Data Base, Center for Global Trade Analysis, Purdue University, West Lafayette, IN.

Francois, Joseph, and Dean Spinanger, 2004, "Liberalizing Quotas on Textiles and Clothing: Has the ATC Actually Worked?" draft, June.

de Gorter, Harry, Melinda Ingco, and Laura Ignacio, 2003, “Domestic Support for Agriculture: Agricultural Policy Reform and Developing Countries,” Trade Note 7, World Bank, September.

International Monetary Fund (IMF), 2005, “Review of the IMF’s Trade Restrictiveness Index,” Policy Development and Review Department, Washington, DC, February 14.

Kee, Hiau Looi, Alessandro Nicita, and Marcelo Olarreaga, 2004, “Import Demand Elasticities and Trade Distortions,” Policy Research Working Paper 3452, World Bank, Washington, DC.

__ _, “Estimating Trade Restrictiveness Indices,” Policy Research Working Paper 3840, World Bank, Washington, DC.

Organisation for Economic Co-operation and Development, 1997, Indicators of Tariff and Non-Tariff Trade Barriers, Paris.

__, 2004, Producer and Consumer Support Estimates: OECD Database, 1986-2003, Paris.

Roodman, David, 2006a, “The Commitment to Development Index: 2006 Edition,” Center for Global Development, Washington, DC, August.

—_, 2006b, “An Index of Donor Performance,” Center for Global Development, Washington, DC, August. 